\title{
South Africa: Report on the Observance of Standards and Codes on Banking Supervision, Insurance Supervision, and Securities' Regulation
}

This Report on the Observance of Standards and Codes on the Banking Supervision, Insurance Supervision, and Securities' Regulation for South Africa was prepared by a staff team from the International Monetary Fund and the World Bank. The views expressed in this document, as well as in the full assessment reports, are those of the staff team and do not necessarily reflect the views of the government of South Africa or the Executive Board of the IMF.

The policy of publication of staff reports and other documents by the IMF allows for the deletion of market-sensitive information.

Copies of this report are available to the public from

International Monetary Fund • Publication Services 700 19th Street, N.W. • Washington, D.C. 20431

Telephone: (202) 6237430 • Telefax: (202) 6237201

E-mail: publications@imf.org • Internet: http://www.imf.org

\section{International Monetary Fund}

Washington, D.C. 


\title{
INTERNATIONAL MONETARY FUND
}

\author{
SOUTH AFRICA
}

\section{Report on Observance of Standards and Codes}

\section{Banking Supervision, Insurance Supervision, and Securities Regulation}

\author{
Prepared by the Monetary and Capital Markets Department
}

Approved by José Viñals

October 21,2010

A joint IMF-World Bank team visited Pretoria and Johannesburg during the period March 15-31, 2010 to assess the observance of key international financial standards as a follow-up to the 2008 FSAP Update for South Africa. The standards covered were: Basel Core Principles for Effective Banking Supervision (BCP), International Association of Insurance Supervisors (IAIS) Core Principles (ICP); and International Organization of Securities Commissions (IOSCO) Objectives and Principles. The assessment team comprised Ian Tower (Co-leader, IMF), Michael Fuchs (Co-leader, World Bank), Katia D’Hulster (World Bank), Jan Rein Pruntel, consultant, IMF), and Jonathan Katz (consultant, World Bank). The exercise was coordinated by Aditya Narain (IMF). The team's main findings are:

- $\quad$ South Africa's regulatory system is fundamentally sound and is substantially compliant with international standards. Banking supervision has been effective and has helped limit the impact on the financial sector of the global financial crisis. The assessment recommended, inter alia, that the bank registrar's remedial powers for addressing problems in banks should be strengthened and that a specific regulation for dealing with country and transfer risk be introduced.

- Insurance regulation is also sound and while the assessment identified areas for development, these are being addressed. The Financial Services Board's (FSB) approach to regulation is thorough, recognizing the scale and development of the South African market, and the need for effective market conduct, as well as prudential regulation. The assessment's key recommendations call for improving standards for market conduct, in both long-term (i.e., life) and short-term (i.e., nonlife) insurance.

- $\quad$ The IOSCO assessment observes significant progress in the FSB's enforcement and onsite inspection programs. The FSB is also undertaking a study of the OTC market, and assessing the need for appropriate regulation of hedge funds and credit rating agencies in South Africa. However, limited progress has been made by the Department of Trade and Industry (DTI) to implement significant amendments to the Companies Act dealing with public company reporting regulation and national accounting policy that were enacted in 2007 and in 2009. If progress continues to lag, consideration should be given to reassigning responsibility for these functions to the FSB.

- $\quad$ The standards assessments highlighted the importance of improving regulatory independence and coordination among regulators. 
Glossary 3

Preface 4

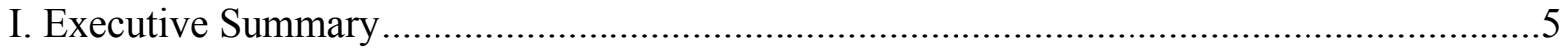

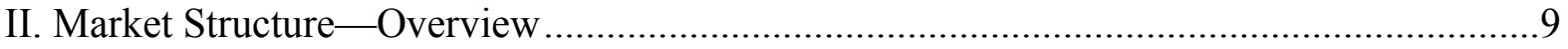

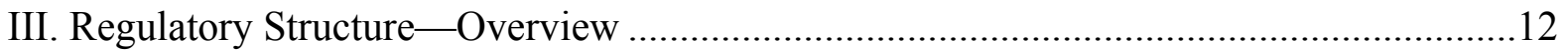

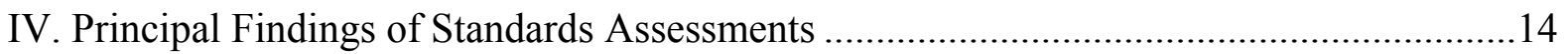

A. Basel Core Principles Assessment …………………….........................................14

B. International Association of Insurance Supervisors Assessment..............................23

C. International Organization of Securities Commissions Assessment........................28

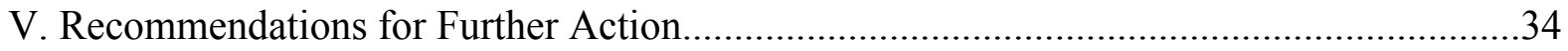

A. Improving Regulatory Coordination and Independence...........................................34

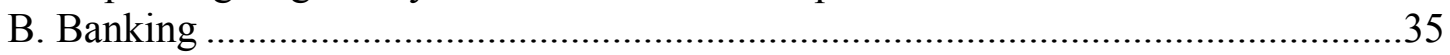

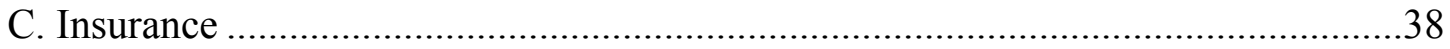

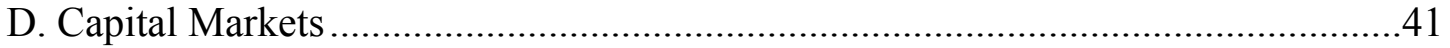

Tables

1. Summary Compliance with the Basel Core Principles .....................................................18

2. Summary of Observance of the Insurance Core Principles .................................................25

3. Summary Implementation of the International Organization of Securities Commissions

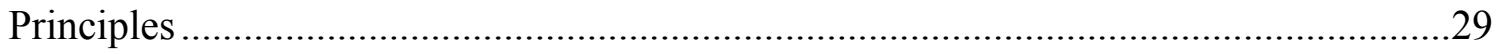

4. Recommended Action Plan to Improve Compliance with the Basel Core Principles..........36

5. Recommended Action Plan to Improve Observance of the Insurance Core Principles .......38

6. Recommended Action Plan to Improve Implementation of the International

Organization of Securities Commissions Principles 


\section{GLOSSARY}

$\begin{array}{ll}\text { AML/CFT } & \text { Anti-money Laundering/Combating the Financing of Terrorism } \\ \text { BCP } & \text { Basel Core Principles for Effective Banking Supervision } \\ \text { BDA } & \text { Broker Dealer Accounting system operated by the Johannesburg Stock Exchange } \\ \text { BEE } & \text { Black economic empowerment } \\ \text { BSD } & \text { Bank Supervision Department of the South African Reserve Bank } \\ \text { BSR } & \text { Bonus Stabilization Reserves } \\ \text { CAR } & \text { Capital adequacy requirement } \\ \text { CFD } & \text { Contract for difference } \\ \text { CIPRO } & \text { Companies and Intellectual Property Commission } \\ \text { CIS } & \text { Collective Investment Schemes } \\ \text { CISCA } & \text { Collective Investment Schemes Control Act, 2002 } \\ \text { CMS } & \text { Council for Medical Schemes } \\ \text { DTI } & \text { Department of Trade and Industry } \\ \text { FAIS } & \text { Financial Advisor and Intermediary Services } \\ \text { FIC } & \text { Financial Intelligence Centre } \\ \text { FICA } & \text { Financial Intelligence Centre Act, 2001 (South African legislation } \\ & \text { encompassing and encapsulating the AML/CTF provisions of FATF) } \\ \text { Forex } & \text { Foreign exchange } \\ \text { FRSC } & \text { Financial Reporting Standards Council } \\ \text { FSAP } & \text { Financial Sector Assessment Program } \\ \text { FSB } & \text { Financial Services Board } \\ \text { FSC } & \text { Financial Sector Charter } \\ \text { FSCF } & \text { Financial Sector Contingency Forum } \\ \text { FSP } & \text { Financial service providers } \\ \text { FTSE/JSE } & \text { Financial Times Stock Exchange JSE All Share index } \\ \text { IAIS } & \text { International Association of Insurance Supervisors } \\ \text { IFRS } & \text { International Financial Reporting Standards } \\ \text { IOSCO } & \text { International Organization of Securities Commissions } \\ \text { IRBA } & \text { Independent Regulatory Board for Auditors } \\ \text { JSE } & \text { Johannesburg Stock Exchange } \\ \text { MoU } & \text { Memorandum of understanding } \\ \text { NCR } & \text { National Credit Regulator (should this capitalized?) } \\ \text { NT } & \text { National Treasury } \\ \text { OTC } & \text { Over the counter securities markets } \\ \text { SAM } & \text { Solvency Assessment and Management Project } \\ \text { SARB } & \text { South African Reserve Bank } \\ \text { SREP } & \text { Supervisory Review and Evaluation Process } \\ \text { SRO } & \text { Self-regulatory organizations } \\ \text { TRP } & \text { Takeover Review Panel } \\ & \end{array}$




\section{PrefaCe}

At the request of the government, a joint IMF/World Bank team visited Pretoria and Johannesburg during the period March 15-31, 2010. The team performed a detailed assessment of the observance of the Basel Core Principles for Effective Banking Supervision and updated the IAIS ICP and IOSCO assessments.

The team expresses its gratitude to the authorities for their cooperation and preparatory work, and extensive discussions with team members on issues and policies related to the South African financial system. The team would also like to thank its counterparts in Pretoria and Johannesburg for the warm hospitality extended during its visit to South Africa. 


\section{EXeCUTIVe Summary}

1. South Africa weathered the global financial crisis better than most countries. A number of factors contributed to this: (i) a generally stable and well capitalized financial sector; (ii) limited exposure of domestic financial services companies to risky foreign assets (such as U.S. sub-prime asset-backed securities) ${ }^{1}$; and (iii) lack of involvement of insurance and other financial companies in wholesale credit protection business (credit default swaps, etc.). Major financial firms, including the largest banks and insurance companies, continued to maintain capital adequacy ratios above the minimum requirements and remained profitable in the aftermath of the crisis. The government of South Africa was not required to provide any financial assistance to the sector and as of the fourth quarter of 2009 , credit impairment trends started to improve.

2. Long-term insurers experienced some strains during the financial crisis, but there were no crisis-related failures. The effects were cushioned, for the most part, by substantial bonus stabilization reserves built up in the strong markets preceding the crisis. ${ }^{2}$ Insurers also benefited from the recovery in markets from the second quarter of 2009. Short-term insurers were less affected, although they suffered investment losses and new business volumes fell. Exposure to hard-to-value structured finance products was limited in both the long- and short-term sectors. Conservative approaches to risk, tight regulation (especially on insurance company investments), and remaining exchange controls $^{3}$ all contributed to the relative resiliency of insurers in the crisis. Regulatory solvency ratios remain strong, as insurers are required to hold free assets equal to, or greater than, the CAR, and the FSB monitors assets in excess of the CAR as a measure of financial health.

3. The South African capital markets suffered sharp declines during the global financial crisis but no systemic failures occurred. The Financial Times Stock Exchange (FTSE)/Johannesburg Stock Exchange All Share index (JSE) closed at 28,747 at mid-April 2010, compared with 27,666 at year-end 2009, and 20,570 at end-January 2009--a healthy rebound following the 26 percent drop in 2008. There were no initial

\footnotetext{
${ }^{1}$ Several firms did suffered losses on investments in debt securities issued by Lehman or due to Lehmanrelated settlement failures.

${ }^{2}$ Bonus Stabilization Reserves (BSR) represent amounts withheld from investment returns that would otherwise be payable to policyholders in the form of bonuses during periods when returns are relatively high. Reserves are then released during periods of low returns so as to avoid the reductions in bonuses that would otherwise then be necessary. Actual approaches vary by product and company and the use of BSRs is subject to regulatory requirements.

${ }^{3}$ The exchange control requirements applying to long-term insurers now limit foreign assets backing retail business to 20 percent of the total (non-linked business) and 30 percent (linked business). This is a transitional regime pending further work on a continued move to reliance solely on prudential limits.
} 
public offerings in South Africa in 2007-09. In addition to the listed market for equities and derivatives, there is a significant over-the-counter (OTC) securities market, largely in an equity-based derivative product called a contract for difference (CFD). In 2009, a customer defaulted on a substantial OTC CFD position, which in turn caused the firm to default on a collateral call on the single stock future position it held as a hedge. No systemic failure occurred however, because under JSE rules the clearing firm for the introducing broker was liable for the position and this firm was sufficiently well capitalized to absorb the loss.

\section{The three standards assessments found that the regulatory system in South} Africa is fundamentally sound. ${ }^{4}$ Substantial progress has been made in addressing the recommendations of the 2000 Financial Sector Assessment Program (FSAP) and is continuing to build upon these accomplishments. The key regulatory agencies, the Bank Supervision Department (BSD) of the South African Reserve Bank (SARB), and the FSB have comprehensive legal authority, sufficient resources, and well-defined regulatory operations.

\section{The National Treasury has broad authority to set and oversee national} regulatory policy. The minister has final authority on appointment and dismissal of FSB board members and senior staff at the FSB, including the executive officer and registrars, and the registrar of banks at SARB. Also, the minister of finance retains final decisional authority for certain core regulatory actions, including adoption of regulations and bank license revocation, and winding down the operations of banks.

\section{Banking supervision has been effective and has contributed to reducing the} impact on the financial sector of the global financial crisis. Throughout the crisis, banks have remained profitable and CARs have been maintained well above the regulatory minimum. The registrar's direct access to the board and the audit committee, combined with the sound governance requirements for banks, have been effective in raising board awareness of regulatory and supervisory matters, and ensuring strong risk management in South African banks.

\section{Insurance regulation is sound and while the assessment identifies areas for} development, these are being addressed. Overall, the FSB takes a thorough approach to regulation, recognizing the scale and development of the South African market, and the need for effective market conduct, as well as prudential regulation. There are features of its work, particularly off-site supervision, which are excellent. The issues raised in the

\footnotetext{
${ }^{4}$ The assessments confirm the broad finding of the 2008 FSAP Update that the regulatory framework for the financial sector is modern and generally effective (see South Africa-Financial System Stability Assessment (SM/08/272), August 19, 2008).
} 
2008 FSAP Update are all being addressed, including deficiencies in the supervision of groups.

8. The legal authority of the FSB has been greatly expanded through a series of new laws and it has increased its staff to implement the new authority. In particular, violations of any law administered by the FSB, including insider trading, market misconduct, and material misstatements by public companies, may now be sanctioned through an administrative tribunal, the Enforcement Committee. The FSB has also expanded its on-site examination program over registered entities and self-regulatory organizations (SRO) and is seeking the legal authority to oversee SRO listing requirements. During the past two years, the FSB has adopted capital adequacy requirements for Financial Service Providers (FSP), and adopted minimum fit and proper requirements for FSP.

9. The standards assessments found substantial compliance and identified areas where further attention is warranted.

10. The BCP assessment recommended that the bank registrar's remedial powers for addressing problems in banks should be strengthened. The registrar cannot appoint a curator at a bank, and there are severe limitations on his authority to cancel or suspend a bank's license. These constraints limit the registrar's ability to act decisively in case of emerging problems at a bank. Also, the CAR should allow for explicit revocation of the advanced approaches for credit and market risk. A specific regulation dealing with country and transfer risk should be drafted. Developing an IT tool that integrates risk analysis, planning of supervisory work, and monitoring of follow-up actions could further strengthen the BSD's approach to risk-based supervision. Accomplishing this will require the BSD to hire additional staff with strong IT skills.

\section{The International Association of Insurance Supervisors (IAIS) assessment} recommended improved standards for market conduct, in both long-term (i.e., life) and short-term (i.e., non-life) insurance. The assessment found that the FSB is committed to major overhauls both of financial requirements (the Solvency Assessment and Management project) and on market conduct (Treating Customers Fairly). This will require increased resources, including specialist skills, to make these projects a success.

\section{The IOSCO assessment described significant progress by the FSB in the} development of its enforcement and on-site inspection programs. It also highlighted an ongoing FSB study of the OTC market, and an initiative to assess what form of regulation, if any, would be appropriate for hedge funds and credit rating agencies in South Africa and to address the sufficiency of its authority in these areas.

13. While the National Credit Regulator (NCR) has developed a strong regulatory presence in a short period of time, the other bodies under DTI have not. The IOSCO assessment discussed the limited progress made by the Department of Trade 
and Industry (DTI) to implement significant amendments to the Companies Act dealing with public company reporting regulation and national accounting policy that were enacted in 2007 and in 2009. Going forward, there should be a careful examination of whether the authority is successfully implemented. If progress continues to lag, consideration should be given to whether responsibility for these functions should continue in the DTI or be reassigned by parliament to the FSB.

\section{The BCP, IAIS, and IOSCO assessments highlighted the importance of} improving regulatory independence and improving coordination among regulators. Parliamentary action is required to address the regulators' operational independence, while government actions could be taken to improve regulatory coordination and ensure that existing regulatory authority is effectively utilized. 


\section{MARKet Structure-OVerview}

\section{Four of the $\mathbf{3 4}$ commercial banks in South Africa dominate the banking}

sector. Combined, their assets represent approximately 85 percent of total banking assets. While the 19 locally-incorporated banks have subsidiaries and branches in foreign jurisdictions, mainly in other African countries, Europe, and Asia, business is heavily concentrated in South Africa.

\section{The total CAR of the banking sector in 2009 improved from 2008 levels-}

14.1 percent from 13 percent. The tier 1 capital adequacy ratio improved from 10.2 percent to 11.0 percent during this period. Total banking sector equity in 2009 was R 198.2 billion, an increase of 9.5 percent from 2008.

17. Insurance companies are major players in the financial sector. The sector is divided between long-term insurance (broadly, life) and short-term (non-life) insurance. Long-term companies' assets are equivalent to about 80 percent of GDP, significantly greater than both total pension fund assets and aggregate mutual funds, and equivalent to two-thirds of total banking sector assets. Insurance penetration - premiums in relation to GDP — is third highest globally at 15.3 percent of GDP (2008). Overall, insurance contributes between 2 percent and 2.5 percent of South African GDP.

18. A key reason for the scale and significance of the long-term insurance sector is its large share of the retirement savings market. Nearly 50 percent of long-term insurance companies' balance sheets are accounted for by the underwriting of retirement fundsretirement savings vehicles, many of which are established and managed as well as underwritten by the insurance company. In addition, long-term insurance companies offer tax-advantageous retirement savings products directly to customers, including various forms of annuity. Increased availability of longer maturity high quality debt instruments would benefit the insurance sector but can be developed only over time.

\section{The insurance sector in South Africa is characterized by:}

- Extensive interrelationships with the banks: in addition to cross-ownership, long-term insurers are major sources of funding for banks. Banks also provide a distribution channel for insurance products although most distribution is via agents and brokers, either tied to the insurance company or independent and servicing the wider market.

- A domestic orientation: with one exception, insurance companies operate only or mainly within the southern Africa region and, in exceptional cases, in the United Kingdom and India. The risks underwritten by long- and short-term insurers are predominantly for domestic customers and, overwhelmingly, retail (including group pensions and employee benefit programs). 
- $\quad$ A relatively advanced product offering: reinsurance and alternative risk transfer products are readily available. However, insurance companies are not engaged in wholesale credit protection business (credit default swaps, etc.) of the kind that led to heavy losses for insurers in some other markets in the global crisis. On the retail side, there has been particular innovation in retirement products and medical coverage - and insurance products for HIV-infected lives. Insurers also offer retail access to hedge funds via linked investment products.

20. The insurance sector suffers from a reputation for high costs and poor treatment of customers in the past, which has led to increased regulatory intervention. A particular issue in the past was the high penalties charged on early termination of retirement and other savings policies - where long-term insurance companies sought to recover full commission (capped by regulation, but mostly paid upfront) and other costs. In 2006 the National Treasury established a wide-ranging program to improve practices in the contractual savings market. Regulations have been made to reduce early termination penalties in the future and limit the commission that can be paid upfront on investment products. There are plans to address wider concerns over the impact of both high costs, including commission, and limited competition on returns available on contractual savings. ${ }^{5}$

21. The sector is also being encouraged to increase access to insurance products for poorer consumers. The Financial Sector Charter (FSC), a 2003 agreement between government and the financial services industry, committed companies to increased penetration of insurance products amongst population groups with the lowest living standards. There are also plans for a micro insurance regulatory regime in the form of a dedicated license, although final proposals are still being worked out.

22. Long-term insurers are particularly exposed to market and certain insurance risks. For many years, they have sold products with both significant guarantees and promises of equity-based returns. Some of the resulting risks are hard to hedge. Longterm insurers are, therefore, structurally exposed to falls in interest rates (which increase the value of guarantees to policyholders), and declining equity markets. They are also exposed to unexpected increases in mortality, particularly from a pandemic or unexpected worsening in HIV/AIDS mortality. Their strong position in the retirement savings markets also exposes long-term insurers to longevity risk on annuities business. ${ }^{6}$

23. Short-term insurers are exposed to a relatively narrow range of risks. Motor business accounts for 40 percent of gross premium income. Although losses due to motor

\footnotetext{
${ }^{5}$ National Treasury Discussion Paper, “Contractual Savings in the Life Industry,” March 2006.

${ }^{6}$ Stress tests done for the 2008 FSAP Update confirmed that long-term insurers were principally exposed to certain market risks and unexpected increases in mortality or longevity.
} 
theft have stabilized (at a high level), accident-related losses are increasing. However, risks of catastrophic loss (earthquake, windstorm, etc.) are low compared with U.S. and European markets. This is reflected in the ready availability of reinsurance cover. However, overall risk retention (around 75 percent) is high, reflecting the predominance of motor risks, which tend to be reinsured less than large industrial and commercial risks.

\section{The JSE is the $\mathbf{1 9}^{\text {th }}$ largest equity market in the world, with a market} capitalization equivalent to 200 percent of GDP. As of 2009, there were 54 equity member firms of the JSE and 419 companies had listed shares. The average number of equity trades per day was more than $83,800 .^{7}$ The JSE also operates as the national derivatives exchange and, following the merger with BESA, a bond trading exchange. It has a well-developed trading market in single stock futures. The equity market is readily accessible to non-residents, in particular following the "head of terms" agreement between the Johannesburg and the London Stock Exchange (LSE) of 2002. The JSE uses the LSE trading system.

25. The JSE remains highly concentrated, with just 70 stocks accounting for 85 percent of its market capitalization. There is also considerable sectoral concentration: mining stocks account for around 40 percent of the JSE's market value, with financial services stocks accounting for a further 20 percent. In October 2003, the JSE launched a new equity market for smaller, emerging public companies called AltX. This market caters to small- and medium-sized companies, and listing requirements are less stringent. Between 2007 and 2010, the number of listed companies grew from 57 to 76. During the same period, the AltX total market grew from $\mathrm{R} 17$ billion to R 21.4 billion. The JSE has also created two more new trading boards. One board will list companies incorporated in neighboring African countries. One such company has listed and another is planning to list. The second new board lists single stock futures in foreign companies, enabling South African investors to invest in foreign companies easily. Recently the JSE announced that it is considering creation of a third new board to permit companies that have issued so-called "black economic empowerment" (BEE) shares to list these securities separately and facilitate better transparency in secondary market trading in these shares.

\section{A very large OTC market exists for derivatives and a small but growing} OTC market exists for interest rate swap/derivatives. There is little regulatory oversight of these markets. Also, there is very little available information on the size or extent of trading activity in the OTC equities market for unlisted companies. In 2010, the FSB determined to initiate a study of OTC trading in derivatives to determine which OTC

\footnotetext{
${ }^{7}$ Data obtained from the January 13, 2010 JSE Market Profile Report. In 2009, 20,950,750 trades occurred over 250 trading days.
} 
instruments should be regulated, and if so, how they should be regulated. A private consultant has been retained to lead the study.

27. The domestic bond market has been growing, although more slowly following the global financial crisis. The JSE bond platform is the trading market for government, local government, and domestic corporation ZAR-denominated debt. In fact, while the JSE provides some small amount of indicative bids and offers for listed securities, secondary market trading in debt securities is largely an OTC market dominated by the leading South African banks. All trading must be reported to the JSE for publication. As of 2009, 1,087 bond issues (from 104 issuers) were listed on the JSE, with a total nominal value of $\mathrm{R} 827.7$ billion. Sovereign government debt represented 53 percent of nominal value and corporate issues accounted for 33 percent of nominal value.

28. The foreign exchange (forex) markets are comparatively well-developed as measured by turnover to GDP ratio. While the spot market is middle-of-the-range, the forex derivatives market is one of the largest. Twenty six authorized dealers including all major commercial and investment banks plus the foreign banks serve the spot market. The derivatives market is dominated by one-week forex swap transactions. At least two-thirds of forex market transactions are with nonresident dealers. Rand futures and options are traded on the Johannesburg-based South African Futures Exchange. Since May 1997, they are also offered on the Chicago Mercantile Exchange, which lists monthly rand futures and options on futures.

29. Collective investment schemes (CIS) (formerly referred to as unit trusts) in South Africa are growing, with total assets under management valued at R 786.1billion as of the end of 2009. This represents 19 percent growth from the previous year. Of the R 786.1 billion at December 2009, money market funds represent 30.3 percent. There were 936 funds, down from 939 in December 2008. CIS are directly regulated by the FSB, which has an extensive regulatory scheme focused on initial registration, capital adequacy and operating compliance. There is a developing hedge fund industry in South Africa, with assets under management estimated at approximately R 30 billion, with approximately R 14 billion additional under-management by funds of hedge funds.

\section{REgUlATORY STRUCTURE-OVERVIEW}

30. The Office of Banks (commonly referred to as the Bank Supervision Division) of the South African Reserve Bank (SARB) has clear authority to register and supervise banks in South Africa. The South African Reserve Bank Act of 1989, together with the Banks Act of 1990 and the Mutual Banks Act of 1993, provide a comprehensive legal framework for banking supervision in South Africa. Under the acts, the Registrar of Banks, as an employee of the SARB, is accountable to the Governor of 
the SARB and also has a direct reporting line to the minister. The minister has final authority to appoint the registrar on the recommendation of the SARB.

31. The FSB was established in $\mathbf{1 9 9 0}$ with the enactment of the Financial Services Board Act (FSB Act). The FSB is subject to the general authority of the minister of finance, who appoints the members of the board and selects the senior officers, after consultation with the board. The responsibilities of the FSB are clearly articulated in the FSB Act and in a series of related laws that have expanded the duties and powers of the FSB. It regulates and supervises the non-bank part of the financial services industry. This encompasses securities firms, the stock exchange, financial advisors and intermediaries (FAIS), CIS operators, pension funds, and insurance companies.

32. The National Treasury has lead responsibility for setting national policy. It develops policy and steers legislation through the parliament and has final authority on regulations prepared by the FSB and the BSD. However, most detailed requirements are issued directly by FSB or BSD as directives, after due consultation. In an effort to improve coordination, the National Treasury created a Regulators Roundtable in 2008. Planning has begun to transform this body into a Council of Regulators chaired by the minister of finance.

33. The DTI oversees the NCR, the Takeover Review Panel (TRP), the Companies and Intellectual Property Commission (CIPRO), and the Financial Reporting Standards Council (FRSC). The NCR is responsible for regulating national consumer credit. The TRP is responsible for reviewing all public company mergers and acquisitions. CIPRO will be responsible for registering all corporations, both public and privately held, and regulating ongoing public company disclosure obligations. The FRSC, when created, will be the national accounting policy standard-setting body.

\section{The Council for Medical Schemes (CMS), which reports to the Department} of Health, regulates medical insurance schemes. While sharing characteristics of insurance, these schemes are closer to social security funds - they do not underwrite individual risks. ${ }^{8}$

\section{The Financial Intelligence Centre (FIC) is a separate unit in the National}

Treasury responsible for anti-money laundering regulation. Created by the FIC Act (FICA) of 2001, its principal objectives are to assist in the identification of the proceeds of unlawful activities and the combating of money laundering and financing of terrorist activities. To achieve its objectives, the FIC must cooperate with other authorities,

\footnotetext{
${ }^{8}$ The council regulates 119 schemes with income of $\mathrm{R} 74$ billion (2008), which compares with a total of $\mathrm{R} 282$ billion in insurance premiums earned in 2008.
} 
including supervisory bodies. However, each supervisory body remains responsible for supervising compliance with the FICA by the institutions it supervises.

36. The JSE is a registered SRO that has broad regulatory responsibilities. The JSE is the primary and secondary market for listed equity securities, financial derivatives, agricultural commodities, and a recently developed bond market. As a licensed SRO, it has primary regulatory responsibility for licensing members (authorized users) and employees, and setting listing standards and disclosure obligations for listed companies. It also has lead responsibility for market surveillance and has the authority to take disciplinary action against member firms and their employees, listed companies, and company directors.

37. South Africa was one of the first countries to permit the use of IFRS, in 1999, and in 2004 IFRS was adopted as South African Generally Accepted Accounting Practice. The Independent Regulatory Board for Auditors (IRBA) was created in 2005 by the Auditing Professions Act and is funded jointly by the government and the accounting industry. It is headed by a 10-member board of governors; appointed by the minister of finance. No more than four members may be audit professionals. IRBA licenses and qualifies auditors. It has an on-site inspection program that reviews firm-wide operations and a disciplinary process. It also has requirements for member firms to formally notify it of "reportable irregularities" identified in the financial statements of a client. The World Economic Forum has recently given a high ranking to the South African accounting profession.

38. The South African regulatory scheme also includes several statutory advisory boards that provide input to the minister of finance, DTI, SARB, or FSB on strategic and policy objectives. These include the Policy Board for Financial Services Regulation (Policy Board), the Financial Markets Advisory Board, the Collective Investment Scheme Advisory Committee, and the Advisory Committee on Financial Services Providers. A Standing Committee on the Banks Act has formal responsibility to review all proposed amendments to the Bank Law and all proposed regulations under the law. A Standing Advisory Committee on Company Law advises the minister of trade and industry on company law matters. In total there are 10 advisory committees and four standing committees that play a role in regulating the financial sector in South Africa.

\section{Principal Findings of Standards Assessments}

\section{A. Basel Core Principles Assessment}

39. Banking supervision in South Africa has been effective and has contributed to reducing the impact of the global financial crisis on the financial sector. Throughout the crisis, the banks have remained profitable and CARs have been maintained well above the regulatory minimum. The registrar's direct access to the board 
and the audit committee, combined with the sound governance requirements for banks, have been effective in raising board awareness of regulatory and supervisory matters and ensuring strong risk management in South African banks.

\section{The banking sector has been helped by the countercyclical fiscal and}

monetary policies over the past two years. ${ }^{9}$ Monetary policy considerations are now evenly balanced given the importance of anchoring inflation expectations and keeping inflation within its target band. The recent steps to integrate banking and financial sector stability issues within the monetary policy decision making framework are an important advance. The authorities have strengthened macro prudential analyses more broadly, and there is further work planned on monitoring how certain shocks might affect the overall financial system.

41. Limited progress has been made in the launching a deposit insurance scheme in South Africa. The National Treasury circulated a draft deposit insurance bill in 2008 to interested parties for comments. Discussions between the relevant parties are ongoing and no timeline for finalization or public consultation of the proposals has been set. A range of challenges complicate this matter, such as the smooth integration into the current supervisory and regulatory landscape, the need to take into account the specificities of the South African financial system, and the predominant role of corporate depositors in previous bank run episodes. In light of the recent draft liquidity proposals issued by the Basel Committee on Banking Supervision in December 2009, the absence of explicit deposit insurance regulation may have an adverse effect on the South African banks.

\section{The SARB implemented Basel II on January 1, 2008 for all banks (including} foreign branches) except the mutual banks which remain on Basel I. The BSD has the authority to set each bank's capital ratio at any time. Currently, minimum Tier 1 ratio is set at 7 percent, with the minimum core Tier 1 ratio at 5.25 percent, and the minimum total capital ratio at 9.5 percent. The 1.5 percent systemic requirement (Pillar 2a charge) on top of the internationally-agreed minimum capital ratio of 8 percent was imposed to align the Basel II underlying assumptions (e.g., the calibration based on a diversified internationally active bank) to an emerging market environment. Although it is subject to continuous assessment, this systemic add-on was last determined at the time of the Basel II implementation 2008 on a capital planning cycle basis (three to five years).

Additionally, banks are required to keep an idiosyncratic capital buffer (Pillar 2b charge), as determined by the registrar reflecting the individual risk profile of the bank. Banks are required to set their target ratios based on the sum of both.

\section{The BSD closely monitors compliance with the minimum capital ratio} reported by the banks. In practice, the registrar will engage with the bank well before

\footnotetext{
${ }^{9}$ For a detailed discussion of the recent macroeconomic policies see 2010 Article IV Consultation-Staff Report, SM/10/296, IMF (September 2010).
} 
the ratio falls below the minimum. During that time, he also has the ability to use a variety of other enforcement powers under the Banks Act and the Regulations, for example the suspension of dividends or the issuance of a directive. The registrar also has the authority to require banks to adopt more forward-looking approaches to capital management. In January 2009, the BSD used moral suasion to encourage the banks to increase their Tier 1 ratio due to the expected changes in market conditions. While there have been no instances of a bank refusing to comply with capital adequacy requirements, the Banks Act allows the registrar to impose fines.

\section{The registrar's approval is required for banks to use the Basel II advanced approaches for credit and operational risk and the internal models method for} market risk. The registrar's approval is based upon accreditation of particular bank's internal risk estimates as regulatory inputs and rigorous qualifying standards. The registrar has the explicit power to revoke accreditation for the operational risk advanced approaches. While there is no explicit power to revoke the advanced approach for credit and market risk, the registrar has included the revocation power in the conditions for approval. The systemic risk-add on and the implementation of idiosyncratic capital buffers have contributed to the strength and stability of the South African banking system.

\section{There are no specific regulations or prudential limits in place for country} risk or transfer risk. The scope of Regulation 39 includes translation risk and concentration risk. For example, banks must establish risk management processes that are sufficiently robust to promptly identify material concentrations with counterparties in the same geographic region. Also, when a bank plans to acquire or establish an off-shore subsidiary, branch, joint ventures or other interest, it must provide the BSD with an evaluation of country and transfer risk of the host country. There is, however, no explicit requirement for banks to continuously monitor and evaluate developments in country risk and in transfer risk and apply appropriate countermeasures. These risks are to be captured in the overall credit risk management framework of banks.

\section{There are significant limitations on the registrar's remedial powers for} addressing problems in banks. The register must obtain the minister's approval to cancel or suspend a bank's registration. Also the registrar must inform the bank, explain its reasons, and provide the bank at least 30 days to argue why its registration should not be cancelled or suspended (BA section 24). During this 30-day period the bank can continue its operations without any restrictions. If the registrar is of the opinion that a bank is unable to meet its obligations, it must ask the minister to appoint a curator. However, this requires the written consent of the chief executive officer or the chairperson of the board of the bank. If a bank has obtained registration by submitting false or misleading information, or - in the case of a foreign bank operating in South Africa-where the home supervisor has revoked the parent bank's license, the registrar needs the consent of the minister to cancel the bank's registration (BA Section 23). These 
limitations seriously inhibit the registrar's ability to use supervisory powers decisively, expediently, and effectively to address serious banking problems.

47. The BSD requires additional staff possessing specialized technical expertise. It needs to expand its expertise in specialized areas such as operational risk (including IT risk) and countering the abuse of financial services (anti-money laundering/combating the financing of terrorism (AML/CFT)). It also needs to expand staff involved in credit risk reviews.

48. Because it has insufficient staff with high level IT skills, the BSD largely relies on banks' internal audit departments and external auditors to assess operational risk. The integrity of bank IT systems is a cornerstone of operational risk management under Basel II because banks rely on historical data for the determination of risk estimates. The BSD's exclusive reliance on internal and external auditors for IT operational risk matters is not in line with international best practice and is a weakness in the overall supervisory approach to operational risk management with banks.

\section{The BSD and the FSB have adopted a memorandum of understanding}

(MoU) on coordination. Regular supervisory meetings are held with the FSB to discuss developments at the five largest banking/insurance groups. The purpose of these meetings is to enhance information sharing, identify issues of mutual interest, and achieve greater consistency of approach. Meetings are also held with the National Credit Regulator (NCR) to exchange views on the credit environment. In addition, the BSD, the FSB, and the SARB's Financial Stability Department hold quarterly meetings to discuss financial sector developments. Supervisory reports are exchanged between the BSD and the FSB on an exceptions basis and there are occasional joint meetings of the BSD and the FSB with senior management of banks.

50. The framework for domestic contingency planning has been strengthened. A Financial Sector Contingency Forum (FSCF) ${ }^{10}$ was created in 2002 to facilitate cooperation in identifying threats to the stability of the South African financial sectors and to develop mutual plans to mitigate such threats and to coordinate responses. In late 2009, two sub-committees were established: the Operational Sub-committee and the Financial Risk Sub-committee. A number of task teams and sub-committees were consolidated into these new sub-committees.

\footnotetext{
${ }^{10}$ Members of the Forum include the SARB, FSB, NT, the Banking Association of South Africa, the Life Offices Association, the South African Insurance Association, the JSE, the Payment Association of South Africa, BANKSERV, and STRATE.
} 
Table 1. South Africa: Summary Compliance with the Basel Core Principles

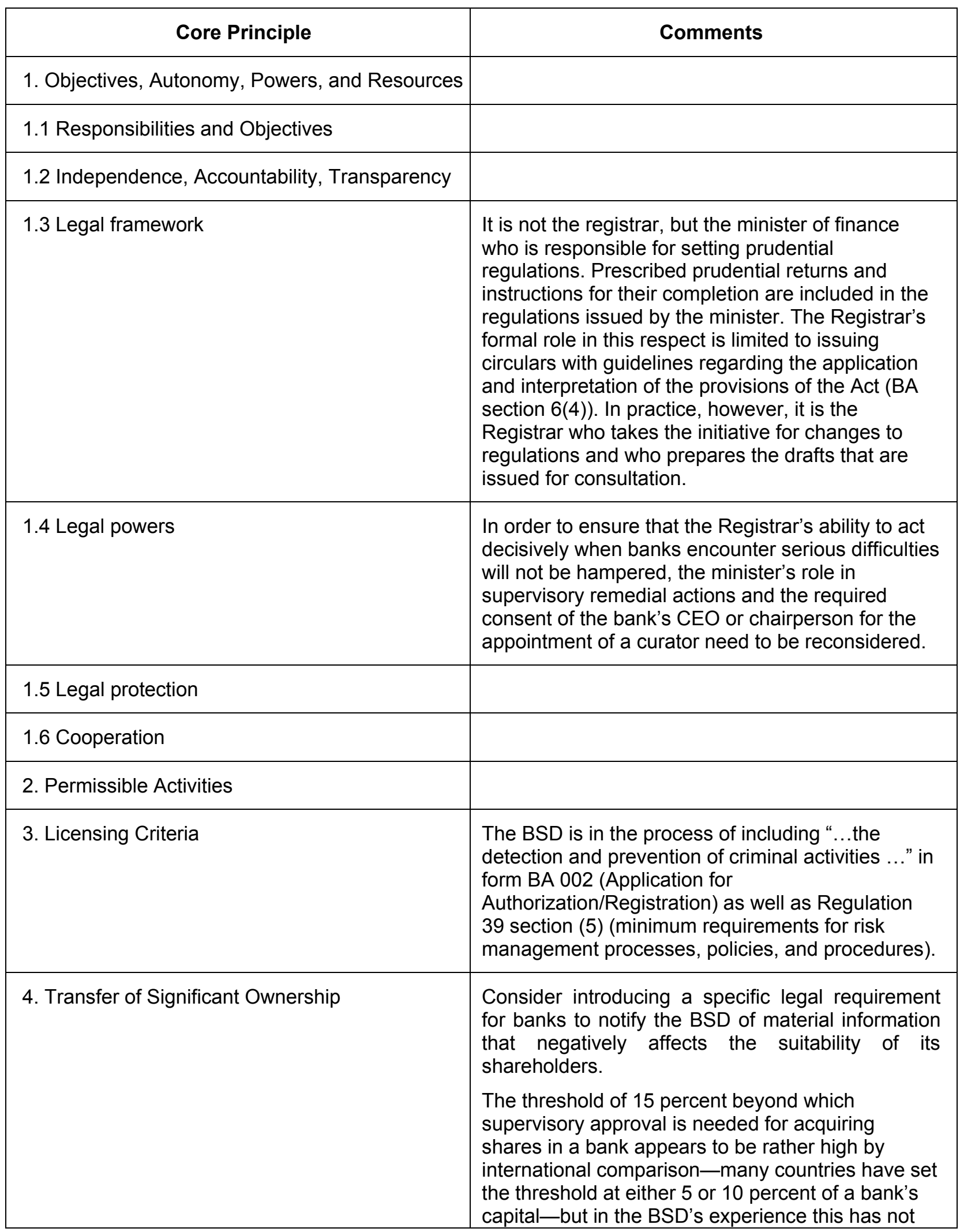




\begin{tabular}{|c|c|}
\hline Core Principle & Comments \\
\hline & caused any problems. \\
\hline \multirow[t]{2}{*}{ 5. Major Acquisitions } & $\begin{array}{l}\text { The Banks Act and the Regulations do not define } \\
\text { the amounts (absolute or in relation to a bank's } \\
\text { capital) of investments by a bank in a subsidiary } \\
\text { that need prior supervisory approval. Neither are } \\
\text { the criteria specified that the Registrar uses for } \\
\text { approving or disapproving proposed investments in } \\
\text { subsidiaries and joint ventures, although to some } \\
\text { extent these are implicit in the information that has } \\
\text { to be submitted with an application for permission } \\
\text { for acquisitions or investments (Regulation 56). }\end{array}$ \\
\hline & $\begin{array}{l}\text { Neither do the Banks Act, nor any Regulation, or } \\
\text { BSD circular clearly indicate for which cases } \\
\text { notification after the investment or acquisition is } \\
\text { sufficient. Apparently all acquisitions and } \\
\text { investments, no matter how small, require the } \\
\text { Registrar's prior approval. The efficiency of the } \\
\text { BSD's use of resources might be increased, and } \\
\text { the burden that supervision puts on the banks } \\
\text { might be reduced, by exempting investments and } \\
\text { acquisitions under a certain threshold from prior } \\
\text { approval. }\end{array}$ \\
\hline \multirow[t]{2}{*}{ 6. Capital Adequacy } & $\begin{array}{l}\text { The BSD is to be commended for its early adoption } \\
\text { and full implementation of the Basel II framework in } \\
\text { an emerging market environment on January } 1 \text {, } \\
2008 \text {, and its continuous efforts to remain in line } \\
\text { with subsequent international developments. }\end{array}$ \\
\hline & $\begin{array}{l}\text { There is no explicit power for the Registrar to } \\
\text { revoke the use of the advanced approaches for } \\
\text { credit or market risk. Although the accreditation } \\
\text { conditions point out that banks need the Registrar's } \\
\text { prior written approval and banks are continuously } \\
\text { required to meet the advanced model user } \\
\text { conditions, an explicit revocation power should be } \\
\text { added to the regulation, similar to Regulation 33(6) } \\
\text { on operational risk. }\end{array}$ \\
\hline \multicolumn{2}{|l|}{ 7. Risk Management Process } \\
\hline \multicolumn{2}{|l|}{ 8. Credit Risk } \\
\hline 9. Problem Assets, Provisions and Reserves & $\begin{array}{l}\text { BSD relies, as part of its supervisory approach, on } \\
\text { the FRS provisions as audited by the external } \\
\text { auditor and the outcomes of the external auditors } \\
\text { report under Regulation } 46(4) \text {. It is recommended } \\
\text { that more specific qualitative guidance on the } \\
\text { BSD's requirements be provided to the external } \\
\text { auditors and/or the banks to ensure that all the } \\
\text { essential criteria of this core principle are } \\
\text { addressed. This applies in particular to areas such }\end{array}$ \\
\hline
\end{tabular}




\begin{tabular}{|c|c|}
\hline Core Principle & Comments \\
\hline & $\begin{array}{l}\text { as the periodical assessment of the value of risk } \\
\text { mitigants, the periodic review of problem assets, } \\
\text { the adequacy of organizational resources for } \\
\text { identification, the oversight and collection of } \\
\text { problem assets, and the timely and appropriate } \\
\text { information to the board of the condition of the } \\
\text { asset portfolio. } \\
\text { The BSD should also clarify its expectations with } \\
\text { regard to forward looking provisioning for prudential } \\
\text { purposes with banks and/or external auditors. More } \\
\text { explicitly, a general allowance for credit impairment } \\
\text { is not a clearly defined concept under IFRS and } \\
\text { part of it may be included in Tier } 2 \text { capital. }\end{array}$ \\
\hline \multicolumn{2}{|l|}{ 10.Large Exposure Limits } \\
\hline 11. Exposures to Related Parties & $\begin{array}{l}\text { The BSD does not obtain on a regular basis } \\
\text { comprehensive information on banks' aggregate } \\
\text { exposures to related parties. It is currently } \\
\text { considering the inclusion of related party exposures } \\
\text { as a separate reportable item on form BA } 600 \\
\text { (Consolidated return which already includes } \\
\text { reporting of group large exposures). Neither does } \\
\text { the BSD obtain regular information on individual } \\
\text { related party exposures, which makes it doubtful } \\
\text { whether it would be able to use its authority to } \\
\text { instruct a bank to deduct such exposures from its } \\
\text { capital effectively. } \\
\text { The BSD does not yet require that transactions with } \\
\text { related parties and the write-off of related party } \\
\text { exposures exceeding specified amounts or } \\
\text { otherwise posing special risk are subject to prior } \\
\text { approval by the bank's board. However, it is } \\
\text { currently in the process of proposing amendments } \\
\text { to Regulation } 36 \text { (15) to include these requirements, } \\
\text { as well as a requirement that persons benefiting } \\
\text { from a particular exposure shall not be responsible } \\
\text { for managing that exposure. In addition, there is no } \\
\text { specific requirement for banks to have policies and } \\
\text { processes to identify individual exposures to } \\
\text { related parties. } \\
\text { Prior board approval is not yet required for a bank's } \\
\text { transactions with related parties in excess of } \\
\text { specified amounts. An amendment to Regulation } \\
36 \text { incorporating such a requirement is currently } \\
\text { under preparation. }\end{array}$ \\
\hline 12. Country and Transfer Risks & $\begin{array}{l}\text { A regulation specifically dealing with country and } \\
\text { transfer risk should be promulgated since these are } \\
\text { material risks to some of the banks. } \\
\text { The granularity of regional exposures on form }\end{array}$ \\
\hline
\end{tabular}




\begin{tabular}{|c|c|}
\hline \multirow[t]{2}{*}{ Core Principle } & Comments \\
\hline & $\begin{array}{l}\text { BA210 should be increased so that the BSD is in a } \\
\text { position to monitor country and transfer risk on an } \\
\text { ongoing basis. }\end{array}$ \\
\hline \multicolumn{2}{|l|}{ 13. Market Risks } \\
\hline \multirow[t]{2}{*}{ 14. Liquidity Risk } & $\begin{array}{l}\text { In view of banks' reliance on wholesale funding, } \\
\text { and the resulting high degree of concentration of } \\
\text { liabilities, the BSD should continue to closely } \\
\text { monitor banks' liquidity management, including } \\
\text { periodic review of liquidity stress testing and } \\
\text { contingency planning. }\end{array}$ \\
\hline & $\begin{array}{l}\text { Where material exposures to foreign currencies } \\
\text { exist, the BSD should ensure that its ALM reviews } \\
\text { include a more in-depth analysis of banks' stress } \\
\text { testing of foreign currency liquidity strategies, and } \\
\text { that the results of such stress testing are a factor in } \\
\text { determining the appropriateness of mismatches. }\end{array}$ \\
\hline \multirow[t]{2}{*}{ 15. Operational Risk } & $\begin{array}{l}\text { It is recommended that the BSD prioritize IT } \\
\text { capacity building within its specialist risk areas in } \\
\text { order to enable it to assess fully and adequately all } \\
\text { aspects of banks' operational risk management and } \\
\text { thus to reduce reliance on the work on IT systems } \\
\text { carried out by external auditors as part of their } \\
\text { certification of the annual accounts. }\end{array}$ \\
\hline & $\begin{array}{l}\text { Board awareness for business continuity was } \\
\text { raised in } 2006 \text { but the BSD should clarify its } \\
\text { requirements into a regulation so that supervisory } \\
\text { expectations are clear. }\end{array}$ \\
\hline \multicolumn{2}{|c|}{ 16. Interest Rate Risk in the Banking Book } \\
\hline 17. Internal Control and Audit & $\begin{array}{l}\text { Corporate governance principles are in accordance } \\
\text { with international standards, as they are inspired } \\
\text { largely by the Basel Committee on Banking } \\
\text { Supervision guidance with respect to internal audit } \\
\text { and internal control. }\end{array}$ \\
\hline \multirow[t]{3}{*}{ 18. Abuse of Financial Services } & $\begin{array}{l}\text { The FICA and other relevant Acts are currently } \\
\text { being revised to implement recommendations } \\
\text { made during a FATF assessment in } 2008 \text {. With } \\
\text { respect to banks, the main FATF recommendation } \\
\text { was that the BA should include a specific provision } \\
\text { allowing the Registrar to impose fines on banks for } \\
\text { offences against the FICA requirements. }\end{array}$ \\
\hline & $\begin{array}{l}\text { The BSD should consider expanding its in-house } \\
\text { expertise on FICA matters. For example, it has no } \\
\text { forensic expertise. For this, it relies exclusively on } \\
\text { external audit firms. }\end{array}$ \\
\hline & The BSD should ensure that all the aspects listed \\
\hline
\end{tabular}




\begin{tabular}{|c|c|}
\hline Core Principle & Comments \\
\hline & $\begin{array}{l}\text { in Essential Criteria 4, 8, and } 9 \text { of the Core } \\
\text { Principles Methodology are specifically addressed } \\
\text { in the Supervisory Review and Evaluation Process } \\
\text { (SREP) Manual. }\end{array}$ \\
\hline \multirow[t]{3}{*}{ 19. Supervisory Approach } & $\begin{array}{l}\text { According to industry sources, the BSD focuses on } \\
\text { the important risk areas within a bank. The BSD's } \\
\text { approach to risk-based supervision could be further } \\
\text { strengthened by developing an IT tool that } \\
\text { integrates risk analysis, planning of supervisory } \\
\text { work and monitoring of follow-up actions. The risk } \\
\text { classification is done on Excel sheets, while the } \\
\text { monitoring system for follow-up actions (the so- } \\
\text { called Issues File) is paper-based. }\end{array}$ \\
\hline & $\begin{array}{l}\text { Interaction between the BSD and the FSB has } \\
\text { been strengthened but can be still further improved, } \\
\text { for example by conducting joint inspections at } \\
\text { group level and by exchanging supervisory reports } \\
\text { on individual groups. See also the comments } \\
\text { under CP } 24 \text {. }\end{array}$ \\
\hline & $\begin{array}{l}\text { The SREP Manual is conceptually sound and the } \\
\text { BSD is encouraged to develop it further, in } \\
\text { particular by including more detailed guidance for } \\
\text { BSD staff in their day-to-day work, but without it } \\
\text { becoming a checklist. }\end{array}$ \\
\hline 20. Supervisory Techniques & $\begin{array}{l}\text { The BSD should consider expanding its staff to } \\
\text { allow it to do more work on credit risk and on } \\
\text { specialized areas such as IT risk and forensic } \\
\text { investigations. }\end{array}$ \\
\hline 21. Supervisory Reporting & $\begin{array}{l}\text { Although the range of periodic prudential returns is } \\
\text { fairly wide, some essential information is not } \\
\text { reported to the BSD on a regular basis. This } \\
\text { includes related party lending (ref. Principle 11) and } \\
\text { country and transfer risk (ref. Principle 12). }\end{array}$ \\
\hline \multicolumn{2}{|l|}{ 22. Accounting and Disclosure } \\
\hline 23. Corrective \& Remedial Powers of Supervisors & $\begin{array}{l}\text { The severe limitations on the registrar's authority to } \\
\text { cancel or suspend a bank's license or to restrict a } \\
\text { bank's activities (BA sections 23-26), in particular } \\
\text { the delay of at least } 30 \text { days between the } \\
\text { announcement of such measures to a bank and } \\
\text { their actual application, call seriously into question } \\
\text { his ability to use these supervisory powers } \\
\text { decisively, expediently and effectively. The same } \\
\text { comment applies to the registrar's inability to } \\
\text { appoint a curator without the consent of the CEO or } \\
\text { the chairperson of the Board of the bank } \\
\text { concerned. }\end{array}$ \\
\hline
\end{tabular}




\begin{tabular}{|l|l|}
\hline \multicolumn{1}{|c|}{ Core Principle } & \multicolumn{1}{c|}{ Comments } \\
\hline 24. Consolidated Supervision & $\begin{array}{l}\text { Interaction between the BSD and the FSB can be } \\
\text { further improved, e.g., by conducting joint } \\
\text { inspections at group level and by exchanging } \\
\text { supervisory reports on individual groups on a } \\
\text { regular basis. Temporary secondments of staff } \\
\text { would help to improve understanding of each } \\
\text { others' approaches and work methods and would } \\
\text { facilitate communication at the operational level. } \\
\text { Consideration could also be given to harmonization } \\
\text { of regulatory requirements in areas of common } \\
\text { interest, such as corporate governance and fitness } \\
\text { and propriety. } \\
\text { The power of the BSD to establish and enforce fit } \\
\text { and proper standards for owners and senior } \\
\text { managers of parent companies of banks is not } \\
\text { clearly stated in the BA (ref. AC 1). }\end{array}$ \\
\hline 25. Home-Host Relationships & \\
\hline
\end{tabular}

\section{B. International Association of Insurance Supervisors Assessment}

51. Insurance regulation in South Africa is generally thorough and effective. The FSB has extensive powers and well-established regulatory processes, as well as adequate resources. The approach to licensing, regulation of persons, and changes in control is thorough and there is an excellent framework for assessing the companies' returns and responding as appropriate. The FSB has developed and is now implementing a risk-based model that will integrate its off-site with its already extensive on-site supervisory work and enable it to prioritize resource allocation. There is a highly developed set of requirements, supported by guidance from the actuarial profession, applying to reserving and capital adequacy, with only minor gaps, in relation to risk and control requirements for investments and derivatives. Available resources appear no more than adequate given the nature of the sector and planned regulatory modernization. There is a need for more risk specialists.

\section{Insurance regulation has seen some significant reforms and initiatives since}

the 2008 FSAP Update. The FSB enforcement program has been significantly strengthened through legislative changes that make it possible for administrative penalties to be levied on insurers for any breach of the regulatory requirements. Capital adequacy requirements have been strengthened, particularly the addition of credit and operational risk requirements for long-term insurers, while higher minimum requirements have been introduced for all life insurance companies_-with a particular impact on linked investment insurers, whose capital requirements were previously low. Regulations have 
been adopted to reduce early termination penalties and limit the commission that can be paid upfront on investment products.

53. The regulation of intermediaries is thorough. There are extensive requirements, under insurance regulation and the law relating to advice and intermediation (FAIS) in relation to consumer protection. Disclosure of financial information by insurers is of a high standard, reflecting the extensive requirements applying to all public companies (which include almost all insurers).

54. Coordination with the BSD is focused on improving group and conglomerate supervision. Communication between banking and insurance supervisors on operational matters in relation to the major conglomerate groups has been intensified and there are moves towards greater coordination.

\section{The Solvency Assessment and Management (SAM) project to overhaul} current requirements for long-term and short-term insurers is intended to achieve equivalency with the EU Solvency II Standards. This will encompass qualitative as well as quantitative requirements. The SAM project delivers some changes in 2012 , although the main impact will be in 2014 . 


\section{Table 2. South Africa: Summary of Observance of the Insurance Core Principles}

\begin{tabular}{|c|c|}
\hline $\begin{array}{c}\text { Insurance Core } \\
\text { Principle }\end{array}$ & Comments \\
\hline $\begin{array}{l}\text { ICP1-Conditions } \\
\text { for effective } \\
\text { insurance } \\
\text { supervision }\end{array}$ & $\begin{array}{l}\text { South Africa has a highly developed framework of laws, institutions and } \\
\text { markets that provide for the preconditions for effective insurance } \\
\text { supervision to be satisfied. Increased availability of longer maturity high } \\
\text { quality debt instruments would benefit the insurance sector but can be } \\
\text { developed only over time. }\end{array}$ \\
\hline $\begin{array}{l}\text { ICP2-Supervisory } \\
\text { objectives }\end{array}$ & $\begin{array}{l}\text { The FSB has a clear vision of its regulatory objectives and publishes } \\
\text { statements of its vision and mission. However, the legislation itself does } \\
\text { not contain regulatory objectives. }\end{array}$ \\
\hline $\begin{array}{l}\text { ICP3-Supervisory } \\
\text { authority }\end{array}$ & $\begin{array}{l}\text { The FSB's supervision of insurance companies is carried out within a } \\
\text { clear framework of powers with a high degree of independence from } \\
\text { government. However, FSB board and executive members may be } \\
\text { removed from office by the Minister of Finance without a requirement } \\
\text { for publication of reasons and the exercise of some powers is subject to } \\
\text { Minister of Finance approval. Available resources appear no more than } \\
\text { adequate given the nature of the sector and planned regulatory } \\
\text { modernization. There is a need for more risk specialists. }\end{array}$ \\
\hline $\begin{array}{l}\text { ICP4 - Supervisory } \\
\text { process }\end{array}$ & $\begin{array}{l}\text { The FSB has extensive regulatory and supervisory processes and its } \\
\text { regulatory requirements are highly transparent both to regulated } \\
\text { companies and more widely. }\end{array}$ \\
\hline $\begin{array}{l}\text { ICP5-Supervisory } \\
\text { cooperation and } \\
\text { information } \\
\text { sharing }\end{array}$ & $\begin{array}{l}\text { The FSB is empowered to exchange information with other domestic } \\
\text { and foreign regulators and does so in practice, with appropriate regard } \\
\text { to the need to ensure confidential information is protected. The FSB } \\
\text { has taken steps to ensure it is ready to communicate as a home } \\
\text { supervisor, where necessary in case of crisis. }\end{array}$ \\
\hline ICP6-Licensing & $\begin{array}{l}\text { Insurance business is subject to licensing requirements and there are } \\
\text { clear minimum requirements. However, licensing requirements do not } \\
\text { sufficiently cover the need for adequate governance, internal controls } \\
\text { and risk management and more friendly societies should fall within the } \\
\text { scope of the insurance legislation. }\end{array}$ \\
\hline $\begin{array}{l}\text { ICP7-Suitability of } \\
\text { persons }\end{array}$ & $\begin{array}{l}\text { The FSB has extensive powers to ensure that key functionaries and } \\
\text { shareholder controllers are fit and proper. It uses its powers to ensure } \\
\text { termination of appointment, or reduction or disenfranchisement of } \\
\text { shareholdings where it has concerns. }\end{array}$ \\
\hline $\begin{array}{l}\text { ICP8-Changes in } \\
\text { control and } \\
\text { portfolio transfers }\end{array}$ & $\begin{array}{l}\text { The FSB operates with appropriate powers and processes to ensure } \\
\text { that changes of control and portfolio transfers are assessed and } \\
\text { approved only where not prejudicial to policyholder interests. There are } \\
\text { some gaps including a requirement on insurance companies } \\
\text { themselves to notify the FSB when they become aware of proposed } \\
\text { changes of control. }\end{array}$ \\
\hline ICP9-Co & While there are no explicit requirements under insurance sector \\
\hline
\end{tabular}




\begin{tabular}{|c|c|}
\hline $\begin{array}{l}\text { Insurance Core } \\
\text { Principle }\end{array}$ & Comments \\
\hline governance & $\begin{array}{l}\text { regulation that insurers comply with general corporate governance law, } \\
\text { insurers are subject to extensive requirements, resulting from a highly } \\
\text { developed framework of Companies Act and voluntary (comply or } \\
\text { explain) standards. }\end{array}$ \\
\hline $\begin{array}{l}\text { ICP10-Internal } \\
\text { controls }\end{array}$ & $\begin{array}{l}\text { The FSB relies extensively on the general corporate governance } \\
\text { framework, sound auditing practices and strong internal control culture } \\
\text { at insurance companies. It is increasingly focusing on the assessment } \\
\text { of control frameworks in its risk-based supervisory framework. } \\
\text { However, given the insurance-specific control failures that have been } \\
\text { experienced, the FSB should consider how it can strengthen internal } \\
\text { control frameworks further in respect to insurance-specific issues. }\end{array}$ \\
\hline $\begin{array}{l}\text { ICP11-Market } \\
\text { analysis }\end{array}$ & $\begin{array}{l}\text { The FSB has an excellent approach to the analysis of reported } \\
\text { supervisory data and publishes aggregate data and the results of its } \\
\text { analysis on the insurance sector. It should consider how to make a } \\
\text { broader analysis of wider information (including market indicators and } \\
\text { information on relevant foreign market developments) and more } \\
\text { frequent exercises to assess the impact of actual or possible market } \\
\text { wide events. }\end{array}$ \\
\hline $\begin{array}{l}\text { ICP12-Reporting } \\
\text { to supervisors and } \\
\text { off-site monitoring }\end{array}$ & $\begin{array}{l}\text { The FSB mandates extensive regular reporting in prescribed form, both } \\
\text { annually and reduced form unaudited quarterly reports. These are } \\
\text { subject to a comprehensive review and analysis process, drawing on } \\
\text { actuarial input and leading to action, where concerns arise. Overall, the } \\
\text { offsite supervision is a considerable strength of the FSB's approach to } \\
\text { supervision, especially in the supervision of solo entities-there is more } \\
\text { to do on groups. }\end{array}$ \\
\hline $\begin{array}{l}\text { ICP13-Onsite } \\
\text { inspection }\end{array}$ & $\begin{array}{l}\text { The FSB has a well-developed approach to onsite supervision that } \\
\text { focuses on key risks and holds management to account for risk } \\
\text { management and addressing areas of regulatory concern. The new } \\
\text { risk-based approach for assessing prudential risks is still being rolled } \\
\text { out but is likely to help the FSB to further focus its supervisory } \\
\text { resources on key risk areas. }\end{array}$ \\
\hline $\begin{array}{l}\text { ICP14-Preventive } \\
\text { and corrective } \\
\text { measures }\end{array}$ & $\begin{array}{l}\text { The FSB has appropriate tools and mechanisms for identifying issues } \\
\text { at individual companies and for responding in a proportionate manner } \\
\text { with escalating severity. With the exception of powers to levy fines } \\
\text { through the Enforcement Committee (see ICP15), which are relatively } \\
\text { new, the FSB's formal powers and readiness to use them are well- } \\
\text { established. }\end{array}$ \\
\hline $\begin{array}{l}\text { ICP15- } \\
\text { Enforcement or } \\
\text { sanctions }\end{array}$ & $\begin{array}{l}\text { The FSB has an extensive range of enforcement powers, which have } \\
\text { been supplemented through new powers (since 2009) to impose fines } \\
\text { on companies and require redress, subject to decision by the FSB } \\
\text { Enforcement Committee. Use of powers is relatively infrequent but they } \\
\text { have been used. There are no powers to bar individuals from acting in } \\
\text { responsible capacities in the future and the FSB's scope to impose } \\
\text { fines against individuals is limited. }\end{array}$ \\
\hline $\begin{array}{l}\text { ICP16-Winding-up } \\
\text { or exit from the } \\
\text { market }\end{array}$ & $\begin{array}{l}\text { The insurance legislation provides for clear triggers for the FSB to take } \\
\text { action in case of an insurance company becoming financially unsound. } \\
\text { In the event of winding-up, however, there is no clear preference for }\end{array}$ \\
\hline
\end{tabular}




\begin{tabular}{|c|c|}
\hline $\begin{array}{l}\text { Insurance Core } \\
\text { Principle }\end{array}$ & Comments \\
\hline & $\begin{array}{l}\text { insurance policyholders; nor is there an insurance scheme that would } \\
\text { pay out in case of policyholder loss on an insurance company } \\
\text { insolvency. }\end{array}$ \\
\hline $\begin{array}{l}\text { ICP17-Group- } \\
\text { wide supervision }\end{array}$ & $\begin{array}{l}\text { The FSB has been developing its approach to supervision of groups, } \\
\text { with more regular and extensive reporting. Cooperation with the SARB } \\
\text { on major conglomerate groups has increased. There are, however, } \\
\text { significant gaps in FSB's powers and the scope of its work, which } \\
\text { focuses mainly on financial soundness and not broader issues of how } \\
\text { groups are managed. The risk assessment model does not address } \\
\text { issues in groups. }\end{array}$ \\
\hline $\begin{array}{l}\text { ICP18-Risk } \\
\text { assessment and } \\
\text { management }\end{array}$ & $\begin{array}{l}\text { The FSB relies on reporting by insurers and its offsite and onsite } \\
\text { supervisory processes to detect and deal with risk assessment and risk } \\
\text { management weaknesses. There is a need, however, for FSB to } \\
\text { provide more feedback and guidance to companies on its observations } \\
\text { and experience of good and bad risk management practices. }\end{array}$ \\
\hline $\begin{array}{l}\text { ICP19-Insurance } \\
\text { activity }\end{array}$ & $\begin{array}{l}\text { The FSB takes an appropriate risk-based approach to the supervision } \\
\text { of insurance risk, relying on the statutory actuary and targeted } \\
\text { consideration of issues in individual companies. }\end{array}$ \\
\hline ICP20 -Liabilities & $\begin{array}{l}\text { Requirements on the establishment of technical provisions are clearly } \\
\text { set out and require insurers to value liabilities appropriately and in } \\
\text { some aspects conservatively. There are clear provisions for the } \\
\text { treatment of reinsurance. The FSB has the authority and expertise, } \\
\text { including in its Actuarial Department, and extensive information } \\
\text { reported by companies, to assess the adequacy of technical provisions. }\end{array}$ \\
\hline $\begin{array}{l}\text { ICP21- } \\
\text { Investments }\end{array}$ & $\begin{array}{l}\text { The FSB has extensive requirements in relation to assets available to } \\
\text { meet solvency requirements-it has adopted a prescriptive approach } \\
\text { (with extensive reporting) rather than a principles-based approach. } \\
\text { However, there are gaps in requirements in relation to risk } \\
\text { management and controls over investments. }\end{array}$ \\
\hline $\begin{array}{l}\text { ICP22-Derivatives } \\
\text { and similar } \\
\text { commitments }\end{array}$ & $\begin{array}{l}\text { The FSB relies on general requirements in relation to financial } \\
\text { soundness, extensive reporting and supervision work to identify and } \\
\text { address issues with use of derivatives. The approach is underpinned by } \\
\text { requirements in the legislation that limit the derivatives activities of } \\
\text { insurers. There is a need for the FSB to develop fuller requirements on } \\
\text { the use of derivatives, drawing on their experience from supervision of } \\
\text { good and bad practice. }\end{array}$ \\
\hline $\begin{array}{l}\text { ICP23-Capital } \\
\text { adequacy and } \\
\text { solvency }\end{array}$ & $\begin{array}{l}\text { The FSB has generally well-developed standards on solvency and } \\
\text { capital adequacy. The approach is more risk-based for long-term than } \\
\text { short-term insurance. The recent extension of the long-term } \\
\text { requirements to incorporate credit and operational risks has } \\
\text { strengthened the approach significantly. Insurance risks, including } \\
\text { annuitant longevity risk, are well-covered. FSB's regime will now be } \\
\text { subject to comprehensive modernization and development by } 2014 \text {, } \\
\text { both for its own sake and to ensure that it can be viewed as equivalent } \\
\text { to the EU Solvency II. FSB could consider reforms to its approach to } \\
\text { solvency control levels. }\end{array}$ \\
\hline
\end{tabular}




\begin{tabular}{|c|c|}
\hline $\begin{array}{l}\text { Insurance Core } \\
\text { Principle }\end{array}$ & Comments \\
\hline $\begin{array}{l}\text { ICP24- } \\
\text { Intermediaries }\end{array}$ & $\begin{array}{l}\text { The FSB's approach to intermediary regulation is relatively complex, } \\
\text { with different, if similar, legislation and rules applying to insurance } \\
\text { companies acting as distributors of their own products compared with } \\
\text { independent intermediaries; and different approaches to supervision. } \\
\text { The approach is still developing. However, it appears comprehensive } \\
\text { and FSB has adequate powers to enforce compliance. }\end{array}$ \\
\hline $\begin{array}{l}\text { ICP25-Consumer } \\
\text { protection }\end{array}$ & $\begin{array}{l}\text { The FSB has a range of rules and requirements addressing key areas } \\
\text { of consumer protection for policyholders at the point of sale and after } \\
\text { sales. A range of ombudsman services provide additional protection in } \\
\text { the case of complaints handling. The FSB is focusing on consumer } \\
\text { protection in its supervisory work, including through thematic programs. } \\
\text { The FSB still observes significant issues in relation to the fair treatment } \\
\text { of customers. The new powers to levy fines and force compensation } \\
\text { will help and FSB is starting a major initiative to improve standards (its } \\
\text { Treating Customers Fairly program-TCF). }\end{array}$ \\
\hline $\begin{array}{l}\text { ICP26- } \\
\text { Information, } \\
\text { disclosure and } \\
\text { transparency } \\
\text { toward markets }\end{array}$ & $\begin{array}{l}\text { While the FSB has limited disclosure requirements, there is a } \\
\text { particularly wide range of information available on the financial position, } \\
\text { management and risks of insurers which are public companies-almost } \\
\text { all. }\end{array}$ \\
\hline ICP27-Fraud & $\begin{array}{l}\text { The FSB has a high degree of awareness of fraud issues and } \\
\text { addresses insurance companies' controls against fraud in its } \\
\text { supervision work. However, only insurance intermediaries and not } \\
\text { insurance companies are subject to specific requirements on fraud } \\
\text { prevention. }\end{array}$ \\
\hline $\begin{array}{l}\text { ICP28-Anti- } \\
\text { money-laundering, } \\
\text { combating the } \\
\text { financing of } \\
\text { terrorism }\end{array}$ & $\begin{array}{l}\text { Requirements in relation to AML/CFT issues for insurers are set out in } \\
\text { the legislation on the Financial Intelligence Center (FIC) and the role of } \\
\text { FSB is to monitor compliance with those requirements and conduct } \\
\text { compliance work. The recent FATF mutual evaluation review } \\
\text { highlighted a number of institutional weaknesses in the South African } \\
\text { approach. It remains for FSB to work with FIC to ensure that overall } \\
\text { relatively weak compliance by insurers improves. }\end{array}$ \\
\hline
\end{tabular}

\section{International Organization of Securities Commissions Assessment}

56. The FSB has made significant progress in building its enforcement program since the 2000 FSAP assessment and 2008 FSAP update. The Enforcement Committee has become an effective forum to take prompt action. In 2009, parliament expanded the jurisdiction of the Enforcement Committee to include all FSB administered laws. This has provided the FSB with an effective vehicle for enforcing compliance.

\section{The FSB has developed an active on-site visit program for FAIS registrants} and CIS registrants. In the past year it has developed a risk-based system for selecting registrants to inspect on-site, in addition to its review of periodic regulatory filings by 
licensees. The risk-based system considers, inter alia, the size of the assets under management the registrant, whether the registrant has discretionary control over customer funds, the adequacy of internal controls for risk management, the number of employees available to perform key functions, and the overall volatility of the relevant market for the products sold. Although there are approximately 14,500 persons or entities registered as financial service providers (FSP), the overwhelming majority are members of the insurance or pension sectors. The FSB estimates that approximately 4000 registered FSPs are involved in providing financial services involving securities. Of these, fewer than 500 have custody or investment discretion over customer assets.

\section{The FAIS staff performs on-site inspections of 400-500 licensees annually.}

These inspections focus on the firms' internal systems for management and accounting of client assets, the segregation of firm and client assets, internal risk management controls, and the firm's compliance office operation. FSB staffs typically review a sample of firm customer files to confirm the accuracy of firm records and consistency of investments with documents indicating investor preferences. As there are only $41 \mathrm{CIS}$ registered managers controlling 936 fund portfolios, the FSB staff has the resources to conduct annual on-site inspections of all CIS registrants. Because JSE-licensed firms are exempted from FAIS, the JSE rather than FSB is responsible for inspections of its member firms.

\section{The lack of a credible program by the DTI to enforce the disclosure} requirements of the Companies Act continues to be a significant problem. Historically, the DTI has focused its resources on the registration of companies. It has largely deferred to the JSE to regulate listed company disclosure. As noted previously, the DTI Disclosure Reporting Investigation Panel was never established and the 2009 Companies Act amendments created CIPRO to supplant it. However, as of March 2010, CIPRO has not been established. Although the Company Act amendments authorized the creation of a Companies Tribunal, modeled after the successful FSB Enforcement Committee, DTI has not implemented this reform. Until CIPRO becomes fully operational and demonstrates that it is a credible enforcer of the Companies Act, there appears to be a substantial void in the regulation of company public disclosures.

\section{Table 3. South Africa: Summary Implementation of the International Organization of Securities Commissions Principles}

\begin{tabular}{|l|l|}
\hline \multicolumn{1}{|c|}{ Principle } & \multicolumn{1}{c|}{ Findings } \\
\hline $\begin{array}{l}\text { Principle 1. The responsibilities } \\
\text { of the regulator should be } \\
\text { clearly and objectively stated. }\end{array}$ & $\begin{array}{l}\text { The South African system of financial services regulation is } \\
\text { complex, involving multiple government agencies, several } \\
\text { advisory or oversight committees, and several self-regulatory } \\
\text { organizations. }\end{array}$ \\
\hline Principle 2. The regulator & The FSB has full control over its budget and daily operations. \\
\hline
\end{tabular}




\begin{tabular}{|c|c|}
\hline Principle & Findings \\
\hline $\begin{array}{l}\text { should be operationally } \\
\text { independent and accountable } \\
\text { in the exercise of its functions } \\
\text { and powers. }\end{array}$ & $\begin{array}{l}\text { However the Minister of Finance has the legal authority to } \\
\text { hire and fire Board members and FSB executive staff. }\end{array}$ \\
\hline $\begin{array}{l}\text { Principle } 3 \text {. The regulator } \\
\text { should have adequate powers, } \\
\text { proper resources and the } \\
\text { capacity to perform its } \\
\text { functions and exercise its } \\
\text { powers. }\end{array}$ & $\begin{array}{l}\text { Since the } 2000 \text { assessment the FSB has obtained greatly } \\
\text { expanded legal authority and has succeeded in building its } \\
\text { capacity to exercise these responsibilities. The FSB lacks } \\
\text { regulatory authority to set disclosure requirements for public } \\
\text { companies. This responsibility is assigned the DTI for all } \\
\text { companies and to the JSE, which includes disclosure } \\
\text { requirements for listed companies in its listing standards. The } \\
\text { DTI subsidiaries charged with these responsibilities in } 2007 \\
\text { were never operational and have been replaced by new } \\
\text { entities, which are not yet operating. }\end{array}$ \\
\hline $\begin{array}{l}\text { Principle } 4 . \text { The regulator } \\
\text { should adopt clear and } \\
\text { consistent regulatory } \\
\text { processes. }\end{array}$ & $\begin{array}{l}\text { The FSB has sound internal operating processes. Its internal } \\
\text { processes have received ISO } 9000 \text { certification. }\end{array}$ \\
\hline $\begin{array}{l}\text { Principle } 5 . \text { The staff of the } \\
\text { regulator should observe the } \\
\text { highest professional standards. }\end{array}$ & $\begin{array}{l}\text { The FSB has a code of conduct, that is in the process of } \\
\text { being revised, for its employees that addresses confidentiality } \\
\text { of information, receipt of gifts from licensed entities and } \\
\text { ownership of securities }\end{array}$ \\
\hline $\begin{array}{l}\text { Principle } 6 \text { The regulatory } \\
\text { regime should make } \\
\text { appropriate use of self- } \\
\text { regulatory organizations } \\
\text { (SROs) that exercise some } \\
\text { direct oversight responsibility } \\
\text { for their respective areas of } \\
\text { competence and to the extent } \\
\text { appropriate to the size and } \\
\text { complexity of the markets. }\end{array}$ & $\begin{array}{l}\text { The JSE and Strate perform several core regulatory } \\
\text { functions. The ASISA, an industry trade group performs } \\
\text { certain regulatory functions, but is not an SRO, subject to } \\
\text { FSB oversight. }\end{array}$ \\
\hline $\begin{array}{l}\text { Principle } 7 . \text { SROs should be } \\
\text { subject to the oversight of the } \\
\text { regulator and should observe } \\
\text { standards of fairness and } \\
\text { confidentiality when exerc ising } \\
\text { powers and delegated } \\
\text { responsibilities. }\end{array}$ & $\begin{array}{l}\text { The FSB has broad authority to license, subject to annual } \\
\text { renewal, its SRO's. Only the JSE and Strate are currently } \\
\text { licensed. The FSB does not have, but is seeking to obtain, } \\
\text { review and approval authority over JSE listing requirements. }\end{array}$ \\
\hline $\begin{array}{l}\text { Principle } 8 \text {. The regulator } \\
\text { should have comprehensive } \\
\text { inspection, investigation and } \\
\text { surveillance powers. }\end{array}$ & $\begin{array}{l}\text { The FSB has strong inspection and investigation powers and } \\
\text { the JSE provides it with surveillance capacity over the listed } \\
\text { market. }\end{array}$ \\
\hline $\begin{array}{l}\text { Principle 9. The regulator } \\
\text { should have comprehensive } \\
\text { enforcement powers. }\end{array}$ & $\begin{array}{l}\text { The FSB has expanded its ability to bring enforcement } \\
\text { actions administratively and it may now use the Enforcement } \\
\text { Committee process to impose substantial sanctions for any } \\
\text { violation of the acts administered by the FSB. In recent years, } \\
\text { the FSB has built a robust investigation and enforcement } \\
\text { program, with many notable accomplishments. }\end{array}$ \\
\hline
\end{tabular}




\begin{tabular}{|c|c|}
\hline Principle & Findings \\
\hline $\begin{array}{l}\text { Principle 10. The regulatory } \\
\text { system should ensure an } \\
\text { effective and credible use of } \\
\text { inspection, investigation, } \\
\text { surveillance and enforcement } \\
\text { powers and implementation of } \\
\text { an effective compliance } \\
\text { program. }\end{array}$ & $\begin{array}{l}\text { The FSB has greatly expanded its inspection and } \\
\text { investigation program since the } 2000 \text { assessment. It has } \\
\text { also developed a strong enforcement program based upon } \\
\text { the expanded authority of its Enforcement Committee system } \\
\text { to adjudicate and sanction violations. There is limited } \\
\text { surveillance capacity over OTC activities of registered } \\
\text { intermediaries. This will be examined as part of an FSB study } \\
\text { on the operation and regulation of the OTC market. The DTI } \\
\text { agencies empowered to investigate financial reporting } \\
\text { violations have not begun operations. }\end{array}$ \\
\hline $\begin{array}{l}\text { Principle } 11 \text { The regulator } \\
\text { should have the authority to } \\
\text { share both public and non- } \\
\text { public information with } \\
\text { domestic and foreign } \\
\text { counterparts. }\end{array}$ & $\begin{array}{l}\text { The FSB has full legal authority to share information with } \\
\text { domestic and foreign regulators }\end{array}$ \\
\hline $\begin{array}{l}\text { Principle 12. Regulators should } \\
\text { establish information sharing } \\
\text { mechanisms that set out when } \\
\text { and how they will share both } \\
\text { public and non-public } \\
\text { information with their domestic } \\
\text { and foreign counterparts. }\end{array}$ & $\begin{array}{l}\text { The FSB has written agreements to share information with } \\
\text { the SARB and the Revenue Authority. The FSB also has } \\
\text { entered into } 50 \text { bilateral MOUs with foreign regulatory } \\
\text { authorities and is a signatory to the IOSCO MMOU }\end{array}$ \\
\hline $\begin{array}{l}\text { Principle 13. The regulatory } \\
\text { system should allow for } \\
\text { assistance to be provided to } \\
\text { foreign regulators who need to } \\
\text { make inquiries in the discharge } \\
\text { of their functions and exercise } \\
\text { of their powers. }\end{array}$ & $\begin{array}{l}\text { The FSB is a signatory to the IOSCO multi-lateral } \\
\text { memorandum of understanding on information sharing. }\end{array}$ \\
\hline $\begin{array}{l}\text { Principle 14. There should be } \\
\text { full, timely and accurate } \\
\text { disclosure of financial results } \\
\text { and other information that is } \\
\text { material to investors' decisions. }\end{array}$ & $\begin{array}{l}\text { Current disclosure standards provide investors with } \\
\text { necessary information on public companies. Responsibility } \\
\text { for setting disclosure requirements is assigned to the DTI for } \\
\text { all companies and to the JSE, through its listing } \\
\text { requirements, for listed companies. While DTI and JSE } \\
\text { review initial offering documents, such as prospectuses, and } \\
\text { documents relating to acquisitions and special transactions, } \\
\text { neither entity routinely reviews periodic disclosure reports, } \\
\text { such as annual reports. These documents may be reviewed } \\
\text { when a complaint is received. Regulatory systems for } \\
\text { proactively reviewing periodic company disclosures could be } \\
\text { improved. }\end{array}$ \\
\hline $\begin{array}{l}\text { Principle } 15 . \text { Holders of } \\
\text { securities in a company should } \\
\text { be treated in a fair and } \\
\text { equitable manner. }\end{array}$ & $\begin{array}{l}\text { The King Commission reports have contributed to an } \\
\text { improved system of corporate governance and accountability. } \\
\text { While proxy solicitation is provided for in the } 2009 \\
\text { Companies Act amendments, there are no procedures in } \\
\text { placing governing a proxy solicitation. }\end{array}$ \\
\hline
\end{tabular}




\begin{tabular}{|c|c|}
\hline Principle & Findings \\
\hline $\begin{array}{l}\text { Principle } 16 . \text { Accounting and } \\
\text { auditing standards should be of } \\
\text { a high and internationally } \\
\text { acceptable quality. }\end{array}$ & $\begin{array}{l}\text { South Africa was an early adopter of IFRS. There is a } \\
\text { national system for oversight of the accounting and auditing } \\
\text { profession. DTI has not yet created the governmental body to } \\
\text { set national accounting policy. }\end{array}$ \\
\hline $\begin{array}{l}\text { Principle } 17 . \text { The regulatory } \\
\text { system should set standards } \\
\text { for the eligibility and the } \\
\text { regulation of those who wish to } \\
\text { market or operate a collective } \\
\text { investment scheme. }\end{array}$ & $\begin{array}{l}\text { CISCA and FAIS provide the FSB with broad regulatory } \\
\text { authority and the FSB has successfully addressed its } \\
\text { responsibilities. Consideration should be given to issues } \\
\text { raised by white label funds. }\end{array}$ \\
\hline $\begin{array}{l}\text { Principle 18. The regulatory } \\
\text { system should provide for rules } \\
\text { governing the legal form and } \\
\text { structure of collective } \\
\text { investment schemes and the } \\
\text { segregation and protection of } \\
\text { client assets. }\end{array}$ & $\begin{array}{l}\text { CISCA established a strong regulatory framework for CIS. } \\
\text { The FSB has used its licensing authority to address issues } \\
\text { concerning segregation of investor assets in LISPs. Legal } \\
\text { gaps complicate the development of a legal form for hedge } \\
\text { funds. }\end{array}$ \\
\hline $\begin{array}{l}\text { Principle 19. Regulation should } \\
\text { require disclosure, as set forth } \\
\text { under the principles for issuers, } \\
\text { which is necessary to evaluate } \\
\text { the suitability of a collective } \\
\text { investment scheme for a } \\
\text { particular investor and the } \\
\text { value of the investor's interest } \\
\text { in the scheme. }\end{array}$ & $\begin{array}{l}\text { While FAIS establishes a legal standard requiring CIS to } \\
\text { provide investors with necessary information, the only } \\
\text { specific disclosure requirements are non-binding industry } \\
\text { codes. }\end{array}$ \\
\hline $\begin{array}{l}\text { Principle } 20 . \text { Regulation should } \\
\text { ensure that there is a proper } \\
\text { and disclosed basis for assets } \\
\text { valuation and the pricing and } \\
\text { the redemption of units in a } \\
\text { collective investment scheme. }\end{array}$ & Regulation of CIS valuation and pricing is sound. \\
\hline $\begin{array}{l}\text { Principle } 21 . \text { Regulation should } \\
\text { provide for minimum entry } \\
\text { standards for market } \\
\text { intermediaries. }\end{array}$ & $\begin{array}{l}\text { The FSB has developed a comprehensive licensing system } \\
\text { implementing its authority under FAIS and CISCA. }\end{array}$ \\
\hline $\begin{array}{l}\text { Principle } 22 . \text { There should be } \\
\text { initial and ongoing capital and } \\
\text { other prudential requirements } \\
\text { for market intermediaries that } \\
\text { reflect the risks that the } \\
\text { intermediaries undertake. }\end{array}$ & $\begin{array}{l}\text { The JSE capital adequacy standards for its licensed } \\
\text { members appear to be sound and the JSE BDA system } \\
\text { provides daily information on member firm open positions } \\
\text { and exposure. In 2009, the FSB adopted capital adequacy } \\
\text { standards for FAIS registrants. An early warning system } \\
\text { under FAIS has not been created. }\end{array}$ \\
\hline
\end{tabular}




\begin{tabular}{|c|c|}
\hline Principle & Findings \\
\hline $\begin{array}{l}\text { Principle 23. Market } \\
\text { intermediaries should be } \\
\text { required to comply with } \\
\text { standards for internal } \\
\text { organization and operational } \\
\text { conduct that aim to protect the } \\
\text { interests of clients, ensure } \\
\text { proper management of risk, } \\
\text { and under which management } \\
\text { of the intermediary accepts } \\
\text { primary responsibility for these } \\
\text { matters. }\end{array}$ & $\begin{array}{l}\text { FSB requires licensees to have internal control processes } \\
\text { and compliance officers. Firms may contract out this } \\
\text { responsibility to compliance companies approved by the } \\
\text { FSB. All client funds must be held in segregated accounts } \\
\text { and licensees must apply "know your customer" principles in } \\
\text { providing financial advice. }\end{array}$ \\
\hline $\begin{array}{l}\text { Principle } 24 \text {. There should be a } \\
\text { procedure for dealing with the } \\
\text { failure of a market intermediary } \\
\text { in order to minimize damage } \\
\text { and loss to investors and to } \\
\text { contain systemic risk. }\end{array}$ & $\begin{array}{l}\text { The FSB and JSE have authority to order licensees to } \\
\text { suspend or terminate operations and the FSB may seek a } \\
\text { court order to appoint a curator. }\end{array}$ \\
\hline $\begin{array}{l}\text { Principle } 25 \text {. The } \\
\text { establishment of trading } \\
\text { systems including securities } \\
\text { exchanges should be subject } \\
\text { to regulatory authorization and } \\
\text { oversight. }\end{array}$ & $\begin{array}{l}\text { The SSA provides comprehensive requirements for } \\
\text { registration of an exchange. The FSB effectively oversees } \\
\text { the operations of the JSE }\end{array}$ \\
\hline $\begin{array}{l}\text { Principle } 26 . \text { There should be } \\
\text { ongoing regulatory supervision } \\
\text { of exchanges and trading } \\
\text { systems, which should aim to } \\
\text { ensure that the integrity of } \\
\text { trading is maintained through } \\
\text { fair and equitable rules that } \\
\text { strike an appropriate balance } \\
\text { between the demands of } \\
\text { different market participants. }\end{array}$ & $\begin{array}{l}\text { The JSE license must be renewed annually. As part of the } \\
\text { renewal process the JSE must submit a written self- } \\
\text { assessment form and the FSB annually performs an on-site } \\
\text { examination. On-going market surveillance is performed by } \\
\text { JSE, with FSB staff oversight through weekly meetings and } \\
\text { reports and regular informal contact. }\end{array}$ \\
\hline $\begin{array}{l}\text { Principle } 27 . \text { Regulation should } \\
\text { promote transparency of } \\
\text { trading. }\end{array}$ & $\begin{array}{l}\text { The systems in South Africa for trading in listed securities are } \\
\text { robust and comparable to international best practices. } \\
\text { Trading in the OTC market, which is substantial in certain } \\
\text { derivative products, is unsupervised. In } 2010 \text { the FSB } \\
\text { initiated a study of the OTC market. }\end{array}$ \\
\hline $\begin{array}{l}\text { Principle } 28 \text {. Regulation should } \\
\text { be designed to detect and } \\
\text { deter manipulation and other } \\
\text { unfair trading practices. }\end{array}$ & $\begin{array}{l}\text { Relying upon JSE listed market surveillance, the FSB has } \\
\text { developed a strong investigative program covering insider } \\
\text { trading, market manipulation and corporate disclosure. } \\
\text { Consideration should be given to the need for market } \\
\text { surveillance in the OTC market and expansion of its } \\
\text { investigation and enforcement program into OTC market } \\
\text { misconduct. }\end{array}$ \\
\hline
\end{tabular}




\begin{tabular}{|l|l|}
\hline \multicolumn{1}{|c|}{ Principle } & \multicolumn{1}{c|}{ Findings } \\
\hline $\begin{array}{l}\text { Principle 29. Regulation should } \\
\text { aim to ensure the proper } \\
\text { management of large } \\
\text { exposures, default risk and } \\
\text { market disruption. }\end{array}$ & $\begin{array}{l}\text { The JSE BDA system provides it with robust data on member } \\
\text { firm exposures. Both the JSE and FSB have the power to } \\
\text { take action in the event of a firm failure to avoid systemic } \\
\text { failures. }\end{array}$ \\
\hline $\begin{array}{l}\text { Principle 30. Systems for } \\
\text { clearing and settlement of } \\
\text { securities transactions should } \\
\text { be subject to regulatory } \\
\text { oversight, and designed to } \\
\text { ensure that they are fair, } \\
\text { effective and efficient and that } \\
\text { they reduce systemic risk. }\end{array}$ & $\begin{array}{l}\text { While the JSE is not legally designated a central } \\
\text { counterparty, it performs a comparable function by acting as } \\
\text { guarantor of all trading on its market. Its system for clearance } \\
\text { and settlement has a strong record, largely because the JSE } \\
\text { may call in replacement securities to cover a delivery failure. } \\
\text { At present it operates on a T+5 standard for equities and a } \\
\text { T+3 for debt. Conversion to a T+3 standard for equities is a } \\
\text { priority, but cannot be implemented until the JSE completes a } \\
\text { large IT system replacement program, which has been } \\
\text { delayed. }\end{array}$ \\
\hline
\end{tabular}

\section{RECOMMENDATIONS FOR FURTHER ACTION}

\section{A. Improving Regulatory Coordination and Independence}

60. While the interaction between the BSD and the FSB has increased, further enhancements are possible. For example, the BSD and FSB could conduct joint inspections at group level and routinely exchange supervisory reports on individual groups. The BSD and FSB licensing programs might also benefit from full exchange of information utilized in making "fit and proper" determinations of key individuals.

\section{The authority of the minister or the SARB to terminate senior FSB or BSD} officials should be defined in law. The minister has unlimited discretion to terminate FSB board members, the FSB chief executive, and the various registrars. Similarly, the Banking Act provides the SARB with unlimited discretion to terminate the registrar of banks. Although any such dismissal would be subject to protections under the Promotion of Administrative Justice Act of 2000, which extends rights to those affected by administrative actions, a finding of good cause or a written explanation for the termination is not required. While the history of the FSB and the BSD does not indicate that a minister or the SARB has used this unfettered discretion improperly, the potential continues to exist.

\section{The banking registrar should have greater authority over suspension or} cancellation of a banking license and the appointment of a curator if a bank is unable to meet its obligations. While it may be appropriate to consult with the minister before suspending or canceling a bank license, the final decision should rest with the registrar. Also, if the registrar determines that a bank curator must be appointed, it should 
not be required to obtain the written consent of the bank's chief executive officer or board chair before requesting a court order.

\section{B. Banking}

\section{The implementation of a deposit insurance scheme with mandatory} membership in the commercial banking sector is needed. Because four banks dominate the banking sector, there is a general perception that the government would intervene to protect depositors. This informal policy should be codified into law to demonstrate that the protection is not received only for the four largest banks. Deposit insurance should primarily aim to protect small depositors and avoid creating ambiguities in bank intervention powers. As the plans for a specific regime for deposit insurance for cooperative banks may progress at greater speed, the implementation of an explicit scheme with mandatory membership in the commercial banking sector is needed to level the playing field and limit the potential for contagion in the banking sector.

\section{The SARB should consider adopting a regulation describing its contingency} planning and crisis management strategies and policies. Besides its regular facilities, the SARB can provide exceptional liquidity assistance against pledged collateral or a government guarantee. Such a regulation would describe the criteria under which banks are able to obtain advances and discounts, outline the lending programs available, indicate the terms and conditions under which the credit is granted, and describe the types of eligible collateral for advances requiring security.

\section{While the overall implementation of the Basel II advanced approaches has} been rigorous and comprehensive, some refinements are warranted. The capital adequacy regulation should allow for explicit revocation of the advanced approaches for credit and market risk. A specific regulation dealing with country and transfer risk regulation should be drafted. Although the exposures are considered relatively small, the BSD does not have a consolidated view of individual country and transfer risk of individual banks. Prudential returns should be expanded to include information on related party lending and country and transfer risk exposures.

\section{Developing an IT tool that integrates risk analysis, planning of supervisory} work and monitoring of follow-up actions could further strengthen the BSD's approach to risk-based supervision. The risk classification is done on excel sheets, while the monitoring system for follow-up actions (the so-called 'Issues File') is paperbased. According to industry sources, the BSD does focus on the important risk areas within a bank. It is recommended that the BSD prioritize IT capacity building within its specialist risk areas, in order to enable it to assess fully and adequately all aspects of banks' operational risk management and thus to reduce reliance on the work carried out by external auditors as part of their certification of the annual accounts. 


\section{Table 4. South Africa: Recommended Action Plan to Improve Compliance with the Basel Core Principles}

\begin{tabular}{|c|c|}
\hline Reference Principle & Recommended Action \\
\hline $\begin{array}{l}\text { Objectives, Independence, Powers, } \\
\text { Transparency, and Cooperation (CP1) }\end{array}$ & $\begin{array}{l}\text { Enlarge the scope for the Registrar to take } \\
\text { remedial action without the Minister's prior } \\
\text { consent. } \\
\text { Reconsider the required consent of the bank's } \\
\text { CEO or chairperson for the appointment of a } \\
\text { curator. }\end{array}$ \\
\hline Transfer of Significant Ownership (CP4) & $\begin{array}{l}\text { Consider requiring banks to notify the BSD of } \\
\text { material adverse information on the suitability of } \\
\text { shareholders. }\end{array}$ \\
\hline Major Acquisitions (CP 5) & $\begin{array}{l}\text { Specify the amounts that banks may invest in } \\
\text { subsidiaries and the criteria the BSD uses for } \\
\text { assessing proposed investments in subsidiaries. }\end{array}$ \\
\hline Capital adequacy (CP6) & $\begin{array}{l}\text { Introduce an explicit revocation power of the } \\
\text { Registrar's approval of the use of advanced } \\
\text { approaches for the calculation of regulatory } \\
\text { capital for market risk and credit risk. }\end{array}$ \\
\hline Problem assets, Provisions, and Reserves (CP 9) & $\begin{array}{l}\text { The BSD relies, as part of its supervisory } \\
\text { approach, on the FRS provisions as audited by } \\
\text { the external auditor and the outcomes of the } \\
\text { external auditors report under Regulation } 46 \text { (4). } \\
\text { Consider providing more specific qualitative } \\
\text { guidance on the BSD's requirements to the } \\
\text { external auditors and/or the banks to ensure that } \\
\text { all the essential criteria of this core principle are } \\
\text { addressed. } \\
\text { Clarify BSD expectations with regard to forward } \\
\text { looking provisioning for prudential purposes with } \\
\text { banks and/or external auditors. }\end{array}$ \\
\hline Exposures to Related Parties (CP 11) & $\begin{array}{l}\text { Obtain regular returns on banks' aggregate and } \\
\text { individual exposures to related parties. }\end{array}$ \\
\hline
\end{tabular}




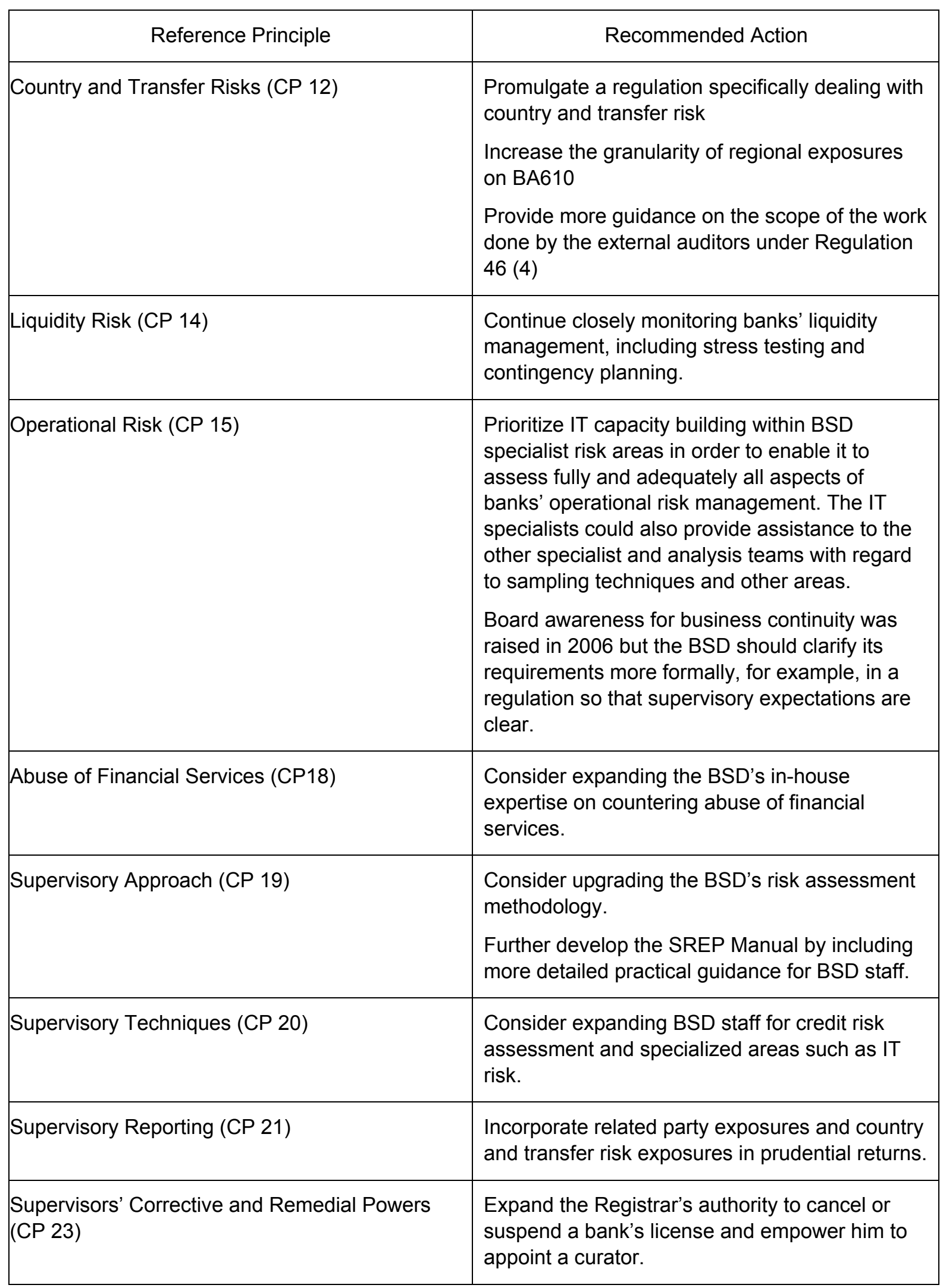




\begin{tabular}{|l|l|}
\hline \multicolumn{1}{|c|}{ Reference Principle } & \multicolumn{1}{c|}{ Recommended Action } \\
\hline Consolidated Supervision (CP 24) & $\begin{array}{l}\text { Further improve the interaction between the } \\
\text { BSD and the FSB. }\end{array}$ \\
\hline
\end{tabular}

\section{Insurance}

\section{There are several areas where further development requires action by} parliament. Legislative change is required to establish a clear priority for policyholders in case of winding up (rare though this has been) and to establish an insurance scheme that would pay out in case of policyholder loss on an insurance company insolvency. FSB enforcement powers should also be extended so that the FSB can bar and fine individuals. Insurance legislation should also be extended to cover more friendly societies and to facilitate supervision of insurance groups, including at the holding company level.

68. The insurance sector would benefit from enhanced interpretive guidance by the FSB. For example, it should develop more requirements setting out its expectations for insurance company internal controls, governance and risk management. Fuller requirements on the use of derivatives should be developed. The FSB could also elaborate its approach to solvency control levels - intervention points above the statutory minimum, as it may be unclear to companies at what level they are expected to maintain capital in practice. While the FSB addresses companies' controls against fraud in its supervision work, there are no specific requirements applying to insurers on fraud prevention.

69. The FSB should expand its internal analytic capacities. For example, it should consider conducting more extensive market wide risk analysis, as well as individual company risk analysis. This and the related challenges of major regulatory reform initiatives will require the FSB to develop skills and expertise of its staff.

\section{Table 5. South Africa: Recommended Action Plan to Improve Observance of the Insurance Core Principles}

\begin{tabular}{|l|l|}
\hline \multicolumn{1}{|c|}{ Principle } & \multicolumn{1}{c|}{ Recommended Action } \\
\hline $\begin{array}{l}\text { ICP2 - Supervisory } \\
\text { objectives }\end{array}$ & $\begin{array}{l}\text { The FSB Act or the legislation on insurance regulation should be } \\
\text { amended to set out objectives of regulation in line with the Insurance } \\
\text { Core Principles. }\end{array}$ \\
\hline
\end{tabular}




\begin{tabular}{|c|c|}
\hline Principle & Recommended Action \\
\hline $\begin{array}{l}\text { ICP3 - Supervisory } \\
\text { authority }\end{array}$ & $\begin{array}{l}\text { Strengthening of the framework is recommended: (i) to enable the } \\
\text { FSB to set all major requirements on insurers via board notices } \\
\text { without reference to government; (ii) to set out causes for which } \\
\text { board and executive members may be removed from office and to } \\
\text { require publication of the reasons in each case; and (iii) to remove } \\
\text { provisions in the insurance legislation for the FSB's exercise of } \\
\text { certain powers to be subject to Minister of Finance approval. }\end{array}$ \\
\hline ICP6 - Licensing & $\begin{array}{l}\text { It is recommended: (i) that license requirements in the legislation are } \\
\text { extended to refer also to the need for adequate governance, internal } \\
\text { controls and risk management; (ii) that legislation is amended to } \\
\text { bring larger friendly societies within the scope of the insurance } \\
\text { legislation; and (iii) that the introduction of a micro insurance regime } \\
\text { is expedited in order to help bring basic protections to all buyers of } \\
\text { insurance. }\end{array}$ \\
\hline $\begin{array}{l}\text { ICP8 - Changes in } \\
\text { control and portfolio } \\
\text { transfers }\end{array}$ & $\begin{array}{l}\text { It is recommended that revisions be made to the legislation to } \\
\text { complete the framework of powers - in particular: (i) to place a } \\
\text { requirement on insurance companies themselves to notify the FSB } \\
\text { when they become aware of proposed changes of control; and (ii) to } \\
\text { establish predetermined control levels in law at which further } \\
\text { approval of controllers is always required. }\end{array}$ \\
\hline ICP10 - Internal controls & $\begin{array}{l}\text { FSB should add to existing requirements in relation to internal } \\
\text { controls with new requirements, in particular on the role of internal } \\
\text { audit and controls over outsourcing. While there are already plans } \\
\text { for work in this area as part of the SAM project, the FSB could } \\
\text { consider some acceleration of this work. }\end{array}$ \\
\hline $\begin{array}{l}\text { ICP15 - Enforcement or } \\
\text { sanctions }\end{array}$ & $\begin{array}{l}\text { It is recommended that (i) the FSB be given powers to bar } \\
\text { individuals from acting in responsible capacities in the future; and } \\
\text { (ii) that its powers to impose penalties on directors, managers and } \\
\text { employees are extended. }\end{array}$ \\
\hline $\begin{array}{l}\text { ICP16-Winding-up or } \\
\text { exit from the market }\end{array}$ & $\begin{array}{l}\text { The FSB should seek reforms to provide that in the event of winding- } \\
\text { up, there is preference for insurance policyholders; or should seek } \\
\text { provisions for an insurance scheme that would pay out in case of } \\
\text { policyholder loss on a insurance company insolvency. }\end{array}$ \\
\hline $\begin{array}{l}\text { ICP17-Group-wide } \\
\text { supervision }\end{array}$ & $\begin{array}{l}\text { It is recommended that: (i) FSB be given additional powers to } \\
\text { enforce requirements for unregulated companies, including holding } \\
\text { companies; (ii) FSB should extend the reporting it requires of the } \\
\text { largest insurance groups to all groups and should ensure that } \\
\text { companies undertaking investment business are included in the } \\
\text { scope of consolidated supervision; and (iii) the FSB could also } \\
\text { further develop its approach to lead regulation of conglomerates in } \\
\text { cooperation with the SARB. }\end{array}$ \\
\hline
\end{tabular}




\begin{tabular}{|l|l|}
\hline \multicolumn{1}{|c|}{ Principle } & \multicolumn{1}{c|}{ Recommended Action } \\
\hline $\begin{array}{l}\text { ICP18-Risk assessment } \\
\text { and management }\end{array}$ & $\begin{array}{l}\text { It is recommended that the FSB commits to providing more feedback } \\
\text { and guidance to companies on its observations and experience of } \\
\text { good and bad risk management practices. }\end{array}$ \\
\hline $\begin{array}{l}\text { ICP19-Derivatives and } \\
\text { similar commitments }\end{array}$ & $\begin{array}{l}\text { FSB should develop fuller requirements on the use of derivatives, } \\
\text { drawing on their experience from supervision of good and bad } \\
\text { practice. It could consider including derivatives management issues } \\
\text { in its thematic supervisory work program. }\end{array}$ \\
\hline ICP21-Investments & $\begin{array}{l}\text { It is recommended that: (i) the FSB develop requirements on risk } \\
\text { management and controls in relation to investment assets, drawing } \\
\text { on their experience from supervision of good and bad practice; and } \\
\text { (ii) they address the lack of requirements in relation to safekeeping } \\
\text { of assets. }\end{array}$ \\
\hline $\begin{array}{l}\text { ICP26-Information, } \\
\text { disclosure, and } \\
\text { transparency toward } \\
\text { markets }\end{array}$ & $\begin{array}{l}\text { It is recommended that the FSB review the full range of disclosures } \\
\text { that would be useful to stakeholders, drawing on IAIS work, and then } \\
\text { consider to what extent these are met by existing requirements on } \\
\text { public companies and where there are gaps in available information. } \\
\text { The FSB should consider whether they can make the } \\
\text { nonconfidential parts of returns more readily available for all } \\
\text { companies. }\end{array}$ \\
\hline ICP27-Fraud & $\begin{array}{l}\text { It is recommended that the adequacy of FSB's powers to make and } \\
\text { enforce fraud requirements under the insurance legislation is } \\
\text { reviewed and that requirements are introduced for insurance } \\
\text { companies. }\end{array}$ \\
\hline
\end{tabular}




\section{Capital Markets}

70. The systems in South Africa for trading in listed securities are robust and comparable to international best practices. The challenge going forward will be to examine trading in the OTC market. There is limited transparency concerning trading in the OTC market. Historically, there was little OTC trading in South Africa. This is changing rapidly. A variety of non-standard OTC derivative products linked to listed equities have developed and trading appears to be growing. Hedging of these OTC products accounts for a substantial percentage of daily trading in listed single stock futures. The FSB should consider the implications of this development and examine how it can fulfill its regulatory responsibilities and promote the development of an OTC market with better transparency.

\section{Careful consideration should be given to transferring the regulatory} functions or entities under the DTI. While the NCR has developed a strong regulatory presence in a short period of time, the other bodies under the DTI have not. There has been no real progress made by DTI implementing the 2007 and 2009 amendments to the Companies Act dealing with regulation of public company reporting and national accounting policy. CIPRO and the Financial Reporting Standards Council exist only in paper, not in reality. If progress continues to lag, consideration should be given to transferring these functions to the FSB or reassigning CIPRO. In the interim, the JSE should begin systemically reviewing the periodic disclosure reports of its listed companies and the FSB should obtain legal authority to review and approve JSE company listing requirements.

\section{The JSE should make conversion to a $\mathbf{T}+\mathbf{3}$ clearance and settlement cycle a} priority when the JSE IT system replacement project is completed. The JSE system replacement project is nearing completion, after several years of delay. Conversion to $\mathrm{T}+3$ is needed to fully interact with other international markets. 


\section{Table 6. South Africa: Recommended Action Plan to Improve Implementation of the International Organization of Securities Commissions Principles}

\begin{tabular}{|c|c|}
\hline Principle & Recommended Action \\
\hline Principle 2 & $\begin{array}{l}\text { The unlimited discretion of the minister of finance to terminate } \\
\text { senior FSB staff and members of the FSB Board should be } \\
\text { defined and limited to circumstances where there is "good } \\
\text { cause." }\end{array}$ \\
\hline Principle 5 & $\begin{array}{l}\text { The FSB should complete the proposed revisions to its rules } \\
\text { for employees to report securities trading, the receipt of gifts } \\
\text { from the industry, and negotiations for employment with } \\
\text { regulated entities }\end{array}$ \\
\hline Principle 7 & $\begin{array}{l}\text { The FSB should obtain legal authority to formally review and } \\
\text { approve JSE listing standards. This authority is included in a } \\
\text { package of proposed amendments to the SSA to be } \\
\text { submitted to parliament in } 2010 \text {. The status of ASISA should } \\
\text { be clarified. If ASISA intends to monitor and police industry } \\
\text { compliance with its codes, then ASISA should apply for an } \\
\text { SRO license. }\end{array}$ \\
\hline Principle 10 & $\begin{array}{l}\text { The CTI must empanel the Companies Tribunal. DTI/CIPRO } \\
\text { must establish a credible program to enforce the Companies } \\
\text { Act. }\end{array}$ \\
\hline Principle 14 & $\begin{array}{l}\text { The JSE should pro-actively monitor ongoing periodic } \\
\text { company disclosure reports. If the DTI does not implement its } \\
\text { legal responsibility to monitor compliance by public } \\
\text { companies with the Companies Act, this authority should be } \\
\text { legally transferred to the FSB. }\end{array}$ \\
\hline Principle 15 & $\begin{array}{l}\text { While the Companies Act permits shareholders to provide } \\
\text { proxies to third parties, there is no regulatory scheme } \\
\text { governing the process for soliciting proxies by third parties. } \\
\text { Company officers should be required to disclose transactions } \\
\text { in the company's securities. }\end{array}$ \\
\hline Principle 16 & $\begin{array}{l}\text { Public companies should be required to publicly disclose any } \\
\text { IRBA notice of accounting irregularities. DTI should quickly } \\
\text { create the Financial Reporting Standards Council and provide } \\
\text { it with sufficient resources to perform its responsibilities. }\end{array}$ \\
\hline
\end{tabular}




\begin{tabular}{|c|c|}
\hline Principle & Recommended Action \\
\hline Principle 18 & $\begin{array}{l}\text { The FSB should complete action on its initiative to develop a } \\
\text { clear legal form for hedge funds, and, as appropriate, an } \\
\text { effective regulatory environment for hedge funds. }\end{array}$ \\
\hline Principle 19 & $\begin{array}{l}\text { The FSB should examine the ASISA codes for marketing and } \\
\text { disclosure by CIS. If the FSB determines them to be } \\
\text { appropriate these codes should be formally adopted as an } \\
\text { FSB directive. }\end{array}$ \\
\hline Principle 21 & $\begin{array}{l}\text { Consideration should be given to creating a new subcategory } \\
\text { under FAIS for CIS portfolio managers. }\end{array}$ \\
\hline Principle 22 & $\begin{array}{l}\text { The capital adequacy requirements under FAIS should } \\
\text { require more frequent calculation of capital and an early } \\
\text { warning notification obligation. }\end{array}$ \\
\hline Principle 23 & $\begin{array}{l}\text { The FSB should consider creating minimum service level } \\
\text { requirements for FSPs who rely upon contract compliance } \\
\text { companies. Consideration should also be given to } \\
\text { establishing minimum resource requirements for compliance } \\
\text { companies on a per client basis. The FAIS division of FSB } \\
\text { should obtain the authority to perform on-site visits of third } \\
\text { party compliance companies. A bill amending the FAIS to } \\
\text { provide this authority has been submitted to Parliament. }\end{array}$ \\
\hline Principle 30 & $\begin{array}{l}\text { A priority goal should be conversion to a } \mathrm{T}+3 \text { equity } \\
\text { settlement cycle. While the JSE role as guarantor of all } \\
\text { trading appears to be effective, legal action to establish a } \\
\text { central counterparty system warrants careful consideration as } \\
\text { it represents the consensus international best practice. }\end{array}$ \\
\hline
\end{tabular}

